\title{
Study of In-Vehicle Pollutant Variation in Public Transport Buses Operat- ing on Alternative Fuels in the City of Toledo, Ohio
}

\author{
Akhil Kadiyala* and Ashok Kumar*
}

Department of Civil Engineering, The University of Toledo, Toledo, Ohio - 43606, USA

\begin{abstract}
This study focuses on determining the variation of indoor pollutants in public transport buses in the City of Toledo running on biodiesel (BD) and ultra low sulfur diesel (ULSD). The indoor pollutants monitored are carbon dioxide $\left(\mathrm{CO}_{2}\right)$, carbon monoxide $(\mathrm{CO})$, sulfur dioxide $\left(\mathrm{SO}_{2}\right)$, nitric oxide $(\mathrm{NO})$, and particulate matter $(\mathrm{PM})$. Temperature (Temp.) and relative humidity $(\mathrm{RH})$ are also measured inside the vehicle in addition to the monitored in-vehicle pollutants. The various factors generally affecting indoor air quality in any microenvironment are indoor sources of pollutants (people, furniture, etc.), ventilation, outdoor air quality, meteorology, pollutant decay, and vehicular traffic. The objective of this research paper is to study the daily, monthly, and seasonal variation of in-vehicle pollutants in relation to different variables and also determine the statistical significance of in-vehicle pollutant levels in biodiesel and ultra low sulfur diesel buses. The daily, monthly, and seasonal variations of the pollutants monitored are studied and it was observed that the pollutant level buildup within a bus compartment is due to a combination of different factors and not a result of variation due to a single variable.

$\mathrm{CO}_{2}$ levels are influenced by a combination of varying passenger ridership, vehicular traffic, ventilation settings, and bus status. $\mathrm{CO}$ and $\mathrm{SO}_{2}$ levels depend on vehicular traffic, ventilation settings, and to an extent on vehicle speed. NO levels varied with vehicular traffic and ventilation settings. PM levels are influenced by vehicular traffic, ventilation settings and vehicle speed. Relatively higher pollutant concentrations are observed for the majority of pollutants in winter months when there is not much air exchange in the bus compartment. A study of the trends revealed that the concentrations were mainly influenced by peak hours, ventilation settings, vehicular traffic, passenger ridership, and meteorology. The pollutant levels of $\mathrm{CO}_{2}$ and $\mathrm{SO}_{2}$ are found to be statistically significantly higher in an ultra low sulfur diesel bus while the pollutant levels of $\mathrm{CO}, \mathrm{NO}$, and particle numbers with size range between $0.30 \mu \mathrm{m}$ and $0.40 \mu \mathrm{m}$ are found to be statistically significantly higher in a biodiesel bus. Particulate matter concentrations are found to be statistically similar in both the test buses.
\end{abstract}

Keywords: Indoor air quality, alternative fuels, biodiesel, ultra low sulfur diesel, transport microenvironment, public transport buses.

\section{INTRODUCTION}

Indoor air quality is one of the major environmental concerns since people spend about $90 \%$ of their time indoors and about $7 \%$ of their daily time commuting, mostly between their workplace and their residence [1]. It has been documented that motor vehicles produce about 1.538 trillion kilograms of carbon dioxide $\left(\mathrm{CO}_{2}\right)$ emissions and the road transportation sector contributes about $56 \%$ of total carbon monoxide (CO) emissions, $38 \%$ of total nitrogen oxides $\left(\mathrm{NO}_{\mathrm{x}}\right), 2 \%$ of particulate matter less than 2.5 micrometer $\left(\mathrm{PM}_{2.5}\right), 1 \%$ of particulate matter less than 10.0 micrometer $\left(\mathrm{PM}_{10.0}\right), 23 \%$ of volatile organic compounds (VOCs), and $2 \%$ of total sulfur dioxide $\left(\mathrm{SO}_{2}\right)$ [2]. Over the years, vehicular usage has been increasing rapidly in combination with a booming growth in population. These factors make air pollution caused by vehicles a potential health hazard. People

*Address correspondence to these authors at the Department of Civil Engineering, The University of Toledo, Toledo, Ohio - 43606, USA; Tel: 419530-8120; Fax: 419-530-8116; E-mails: akadiya@ rockets.utoledo.edu, akumar@utnet.utoledo.edu are exposed to higher levels of traffic pollutants when they drive in heavy traffic, stand near idling vehicles, and spend time at places near roads having high traffic, especially if the location is downwind of the road [3]. The degree of exposure level to pollutants is more for people commuting in a bus as compared to the levels of exposure occurring at bus stops or during loading and unloading [4]. Therefore, a careful study needs to be done to evaluate the exposure levels to people commuting in different transport microenvironments and the factors influencing pollutant levels. Many studies have been conducted to find the exposure of people to indoor air pollutants inside homes, schools and offices, and vehicle emissions as compared to studies that have focused on studying the exposure to in-vehicle pollutants.

Numerous studies are reported in the literature to assess the personal exposure to different pollutants in different vehicle microenvironments. Also, some of these studies have identified the factors that influence the in-vehicle pollutant levels. A study of in-vehicle pollutant concentration variations is more complex as compared to the study in buildings due to the fact that the vehicle is always in a mobile condi- 
tion. A study on the children's exposure to different pollutants while commuting in a school bus identified vehicle exhaust and self intrusion as influential factors affecting invehicle pollutant levels when the windows were closed, while ventilation settings were found to play a major role when the windows were open [5].

A study of exposure to $\mathrm{PM}_{10.0}, \mathrm{PM}_{2.5}$, metals, thirteen organic compounds, $\mathrm{CO}$, fine particle counts and black carbon by California Air Resource Board identified driving lane, roadway type, congestion level, time of day, and exhaust from lead vehicles as significant factors affecting the pollutant concentrations [6]. Road type, following distance between the lead vehicle and follow vehicle, and exhaust location of the lead vehicle were observed to be the important factors affecting vehicular pollutant concentrations where the pollutants studied are black carbon, ultra fine particles, oxides of nitrogen, carbon monoxide, carbon dioxide, $\mathrm{PM}_{2.5}$, PM size distribution and PM-bound PAH [7].

Outdoor concentrations and traffic were found to have an impact on particulate matter concentrations in Munich public transportation systems that included buses and trams [8]. Route selected was found to be significantly affecting the $\mathrm{PM}_{2.5}$ exposure levels for transport users as compared to the mode selected, and a combination of both the variables accounted for one-third of the exposure variation in a study having four different microenvironments that included bicycle, bus, car, and underground railway in London, UK [9]. Lead vehicle and type of test bus were observed to be the influential factors affecting in-vehicle pollutant levels when the windows are opened and closed respectively after considering the exposure to black carbon, particle bound polycyclic aromatic hydrocarbons, and nitrogen dioxide in school buses in Los Angeles [10]. Relationships for indoor air quality were developed using regression analysis for $\mathrm{CO}_{2}, \mathrm{CO}$, $\mathrm{SO}_{2}$, and $\mathrm{PM}$ in public transport buses operating in Toledo, Ohio [11].

Passenger exposure to emissions of benzene, toluene, xylene, and formaldehyde in parked vehicles in the underground parking, i.e., exposure to emissions from materials in passenger cabins revealed that the emissions monitored were found to be higher in new vehicles compared to older vehicles [12]. Similar observations were made in another study on comparing the VOC levels in old and new vehicles [13]. The study also identified interior temperature, vehicle make, vehicle age, and the type of deodorizer used to play an important role in influencing the VOC levels. Providing ventilation during driving helped reduce the VOC levels significantly by 4-20 times compared to the levels obtained under a stationary condition. Exposure to about 24 gasoline related VOC's simultaneously with ozone, $\mathrm{CO}$, and $\mathrm{NO}_{2}$ was investigated; and road types, driving time, and air conditioning were found to significantly influence the monitored pollutant levels [14].

Exposure to $\mathrm{PM}_{10.0}$ and ultra fine particles on-road and in-vehicle were studied and it was observed that the exposure was higher in areas of heavy traffic and during peak hours [15]. It was also observed that the on-road levels were influenced by rush hours while in-vehicle levels were influenced by the stop and go traffic predominantly found at signals. Exposure of passengers to VOCs in four different pub- lic commuting modes - taxi, subway, air conditioned bus, and non-air conditioned bus was studied; and it was observed that passenger exposure was influenced by the commuting mode selected by the passenger [16]. Similar observations were made by another study in Guangzhou, China where the pollutants studied are particulate matter and carbon monoxide [17]. The study also reported lane of travel, air conditioning system, internal sources, and ventilation settings to impact the in-vehicle levels, while driving time was not found to be important.

A study of exposure to $\mathrm{CO}$ in three different commuting modes - bus, minibus, and taxi concluded that the exposure apart from being influenced by heavy traffic and street configuration was increased by 2-3 times in tunnel microenvironment compared to urban and sub-urban roads [18]. The study also reported vehicle height, size of the vehicle, leakage and intake positions of ventilation systems to affect pollutant levels while much variation is not observed between levels in air conditioned and non-air conditioned vehicles. The influence of peak hours, road type, and ventilation settings on in-vehicle concentrations of 1-3 butadiene and benzene was studied, and it was observed that the in-vehicle concentrations were found to be $50 \%$ higher inside the bus compared to new cars and $25 \%$ higher than old cars [19].

A study of exposure to $\mathrm{PM}_{1.0}, \mathrm{PM}_{2.5}$, and $\mathrm{PM}_{10.0}$, during walking and in-car travel in Northampton, UK showed that the exposures were higher in the case of cars compared to those walking [20]. Exposure to $\mathrm{PM}_{2.5}, \mathrm{CO}$, benzene, and chemical composition of $\mathrm{PM}_{2.5}$ was studied on three different transportation modes and it was observed that low wind speed contributed to higher $\mathrm{CO}$ and $\mathrm{PM}_{2.5}$ concentrations [21]. Another study of exposure to CO levels in five different commuting modes that included bus, collective taxi, minibus, auto, and metro in Mexico City identified road lane used and vehicle size to affect the CO levels [22].

A study of driver exposure to $\mathrm{CO}$ in Nottingham, UK observed air conditioning to play a major role in influencing invehicle pollutant levels [23]. Similar observation was made in a study of exposure to $\mathrm{PM}_{10.0}$ and $\mathrm{PM}_{2.5}$ in over eight different transportation modes [24]. Exposure to aromatic VOCs were studied in nine different commuting modes that included tram, public light bus, air-conditioned bus, non airconditioned bus, taxi, ferry, and three railway systems comprising of Mass Transit Railway-MTR, Kowloon-Canton Railway-KCR, and Light Rail Transit-LRT; and it was observed that VOC levels were influenced by the mode of transport [25]. A study of exposure to $\mathrm{CO}$, nitric oxides, total hydro carbons, and ozone in six different commutes in Hong Kong concluded vehicle body position, intake point of ventilation, ventilation effect, transportation mode, road type, driving conditions, and relative distance from emission source to possibly affect the pollutant levels [26].

Exposure to VOCs from six main roads were studied in Taichung, Taiwan and it was observed that the VOCs were not correlated to traffic density which was in contradiction to the findings of other studies [27]. Study of exposure to $\mathrm{CO}$ and $\mathrm{CO}_{2}$ in different buses inside and outside using portable monitors showed that in-vehicle levels are 10 times higher compared to outdoors, and $\mathrm{CO}_{2}$ levels were mainly influenced by passengers and not the driving environment [28]. 
Another study of exposure to PM and $\mathrm{CO}$ along a standard route identified higher in-vehicle levels to be a result of higher traffic, and exposure to pollutants were influenced by time of the day, average speed, wind speed, and relative humidity [29]. A $\mathrm{PM}_{2.5}$ exposure study in transport microenvironment in the UK observed that there was considerable variation in exposure levels based on the route selected [30]. In-vehicle particle number concentrations on clean diesel, retrofitted diesel, and non-retrofitted diesel school buses were studied; and it was observed that retrofit diesel buses produced less in-vehicle particle number concentrations [31]. It was also observed that particle number concentrations were found to be significantly affected by engine age, bus idling behavior, and ambient particle concentrations. A study of exposure to $\mathrm{CO}$ in Athens area observed transport mode, route selected, monitoring period, and season to be affecting vehicular CO levels [32]. Statistical significance of occupant exposure was studied along with temporal variation of invehicle pollutant concentrations of $\mathrm{CO}_{2}, \mathrm{CO}, \mathrm{SO}_{2}, \mathrm{NO}, \mathrm{NO}_{2}$, and $\mathrm{PM}_{2.5}$ in public transport buses operating on alternative diesel fuels in Toledo, Ohio [33]. It was observed that the mean 8-hour exposure to $\mathrm{CO}_{2}$ and $\mathrm{SO}_{2}$ were found to be significantly higher inside ULSD buses as compared to B20 fueled buses, while the $\mathrm{CO}$ and $\mathrm{NO}$ concentrations were found to be higher inside B20 buses. The study also observed exposure to $\mathrm{NO}_{2}$ and $\mathrm{PM}_{2.5}$ to be statistically similar for both the buses and none of the pollutants monitored except $\mathrm{CO}$ exceeded the TWA limits.

Many studies have also found in-vehicle pollutant concentrations to be many times higher than those observed in ambient air [6, 34-36]. Only a few studies are reported in the literature that have summarized the personal exposure studies to pollutants like $\mathrm{PM}_{2.5}$, ultrafine particles, and $\mathrm{CO}$ in a traffic microenvironment [37-39].

From the personal exposure studies reported in the literature in the case of pedestrians and cyclists, it can be stated that the exposure to pollutants inside a vehicle were consistently higher compared to those outside the vehicle. It was also observed that the pollutant exposure was found to be higher in congested roads where there was heavy traffic and during the peak hours. Many studies reported communities that are nearby roads have higher exposure to pollutants coming from exhausts. All the vehicular studies reported in the literature have used regression analysis to determine the influential factors except for a few studies where regression tree analysis was used to find the factors affecting in-vehicle pollutant levels [40-42]. A couple of studies observed regression tree analysis to perform better than regression analysis on comparing their performances with the monitored in-vehicle pollutants of $\mathrm{CO}_{2}, \mathrm{CO}, \mathrm{NO}, \mathrm{NO}_{2}, \mathrm{SO}_{2}$, and $\mathrm{PM}[40,42]$. One study determined the influential factors affecting in-vehicle levels of $\mathrm{CO}_{2}, \mathrm{CO}, \mathrm{NO}, \mathrm{NO}_{2}$, and $\mathrm{SO}_{2}$ pollutants on a monthly, seasonal, and yearly basis using regression tree analysis [41]. From the review of vehicular studies, it was observed that the in-vehicle pollutant levels were influenced by meteorological conditions, characteristics of vehicle (old or new), vehicular traffic, exhaust pipe location of lead vehicle, ventilation settings, lead vehicle type, etc. However, most of the studies have used only a limited number of variables that could possibly influence the in- vehicle pollutant concentrations and were conducted over a shorter period due to the cost of conducting experiments. Only a few studies have monitored real time on-road variables continuously over a longer period of time along with the indoor concentrations [11,41-43]. This study is a part of the research to determine the variation of in-vehicle pollutants over a period of one year for both BD and ULSD buses. None of the studies reported in the literature have determined the trends of indoor vehicular pollutants for over a year and compared the indoor air quality for vehicles operating on alternative fuels. The research objective of this paper is to study the daily, monthly, and seasonal variation of in-vehicle pollutants in relation to different variables.

\section{DATABASE DEVELOPMENT}

The methodology adopted in database development is discussed briefly in this section. A couple of studies have provided a comprehensive discussion on the experimental setup used for monitoring indoor pollutants in any vehicular microenvironment without concerns to the safety of the instrument and power supply to the instruments over longer periods of time $[33,42]$. Daily real-time in-vehicle pollutant concentrations were obtained using Grimm 1.108 Dustmonitor, Yes Plus, and TSI Dusttrak ${ }^{\mathrm{TM}} 8520$ instruments. While Grimm and Dusttrak instruments are used to measure the vehicular particulate matter levels, Yes Plus instrument is used to measure gaseous pollutants that included carbon dioxide $\left(\mathrm{CO}_{2}\right)$, carbon monoxide $(\mathrm{CO})$, nitric oxide (NO), and sulfur dioxide $\left(\mathrm{SO}_{2}\right)$. In addition, the Yes Plus instrument also measures two important indoor air quality comfort parameters: temperature and relative humidity simultaneously. "Grimm 1.108" is a sub-micron aerosol spectrometer developed by Grimm Technologies, Inc., [44] used by the researchers to monitor the sub-micron in-vehicle particulate matter levels or particle counts. "Dusttrak ${ }^{\mathrm{TM}} 8520$ " is another particulate matter monitoring instrument developed by TSI Inc., [45] used by the researchers to monitor in-vehicle particulate matter levels. "Yes Plus" is a 15 channel multi-gas air quality monitoring instrument developed by Critical Environmental Technologies [46] used by the authors to monitor in-vehicle gaseous concentration levels. Refer to Table $\mathbf{1}$ for more details on the instrumentation working capabilities.

The fleet selected for the study was the 500 series Thomas built buses (acquired by Detroit Diesel) of the Toledo Area Regional Transit Authority (TARTA) line up, with a Mercedes Benz MBE 900 engine and the route selected was Route \# 20 (refer Fig. 1) which runs between the TARTA garage (A) and Meijer (B) on West Central Avenue strip in Toledo, Ohio. After selecting the fleet, each bus was checked if all the cameras inside the bus are working. Two buses were selected from the 500 series in which all the cameras are in working condition with one bus running on BD (ID: 506 with $106 \mathrm{~K}$ engine miles acquired by TARTA in 2003) and the other running on ULSD (ID: 536 with $108 \mathrm{~K}$ engine miles acquired by TARTA in 2003) to assess the in-vehicle air quality. Both the buses are "Thermo King" air conditioned and outdoor air penetrates indoors mainly through the windows (no: 10) and doors (no: 2) when opened. Both the selected test run buses operated on the same route with a time lag of 12-20 minutes between each run. 
Table 1. Instrumentation Details

\begin{tabular}{|c|c|c|c|}
\hline Instrument & Component Monitored & Range & $\begin{array}{c}\text { Component } \\
\text { Tolerance }\end{array}$ \\
\hline \multirow{2}{*}{$\begin{array}{l}\text { GRIMM } 1.108 \\
\text { Dustmonitor }\end{array}$} & $\begin{array}{l}\text { Environmental Mode }\left(\mathrm{PM}_{10.0}, \mathrm{PM}_{2.5} \text {, and } \mathrm{PM}_{1.0}\right) \text { or Mass Mode }\left(\mu \mathrm{g} / \mathrm{m}^{3} \text { in } 15 \text { size }\right. \\
\text { channels) or Occupational Mode (lnhalable, Thoracic, and Respirable). }\end{array}$ & 0.1 to $100,000 \mu \mathrm{g} / \mathrm{m}^{3}$ & $\pm 2 \%$ \\
\hline & Particle Counts (particles/liter in 15 size channels) & $\begin{array}{l}1 \text { to } 2,000,000 \text { particle } \\
\text { counts/liter }\end{array}$ & $\begin{array}{l}1 \text { particle } \\
\text { count/liter }\end{array}$ \\
\hline $\begin{array}{l}\text { TSI Dusttrak } \\
\quad 8520\end{array}$ & $\mathrm{PM}_{10.0}$ (or) $\mathrm{PM}_{2.5}$ (or) $\mathrm{PM}_{1.0}$ & $0.001-100 \mathrm{mg} / \mathrm{m}^{3}$ & $\pm 0.001 \mathrm{mg} / \mathrm{m}^{3}$ \\
\hline \multirow{6}{*}{$\begin{array}{l}\text { Yes Plus IAQ } \\
\text { Monitor }\end{array}$} & $\mathrm{CO}_{2}$ & $0-5000 \mathrm{ppm}$ & $\pm 50 \mathrm{ppm}$ \\
\hline & $\mathrm{CO}$ & $0-50 \mathrm{ppm}$ & $\pm 0.5 \mathrm{ppm}$ \\
\hline & NO & $0-100 \mathrm{ppm}$ & $\pm 0.2 \mathrm{ppm}$ \\
\hline & $\mathrm{SO}_{2}$ & $0-20 \mathrm{ppm}$ & $\pm 0.1 \mathrm{ppm}$ \\
\hline & Temperature & $5^{\circ} \mathrm{C}-50{ }^{\circ} \mathrm{C}$ & $\pm 0.5^{\circ} \mathrm{C}$ \\
\hline & Relative Humidity & $\begin{array}{l}0 \%-99 \% \text { non- } \\
\text { condensing }\end{array}$ & $\pm 5 \%$ \\
\hline
\end{tabular}

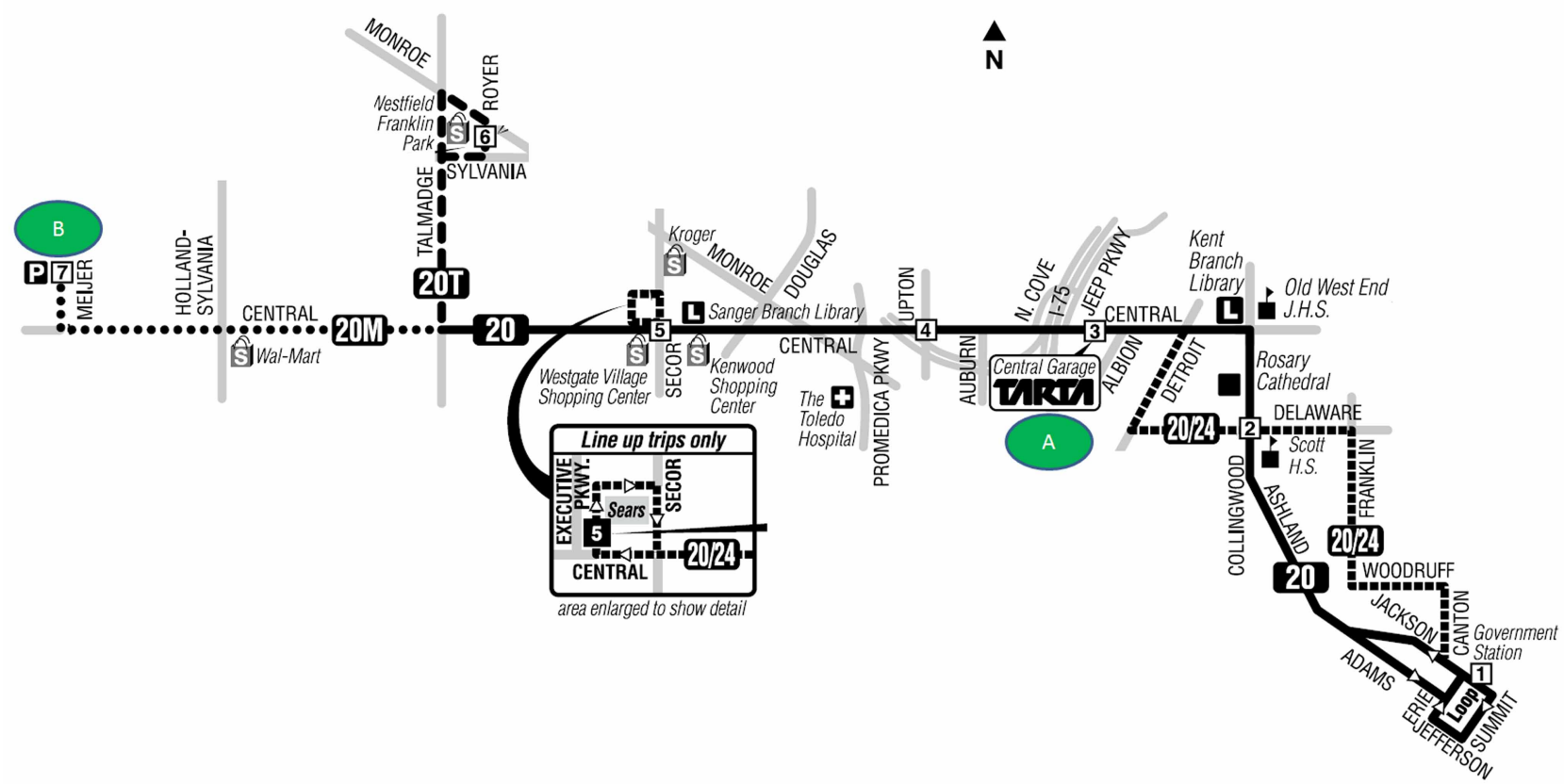

Fig. (1). Map showing route \# 20 [47].

Indoor air quality was monitored 24 hours a day, seven days a week $(24 \times 7)$ by the three instruments on a 1 -second interval and provided the output as 1-minute averages that were stored in the in-built memory cards. The collected data were frequently downloaded to a laptop to ensure proper working of the instruments and the average hourly pollutant concentrations are computed. To study the effect of meteorology on indoor air quality, the unedited local climatological data which consists of unedited hourly details of ambient temperature, ambient relative humidity, wind speed, wind direction, total precipitation, and visibility were downloaded from the National Climatic Data Center website [48] and formatted to obtain the hourly details. Ambient $\mathrm{PM}_{2.5}$ concentrations were obtained from U.S EPA on request. Other real-time variables such as passenger count, vehicular traffic in the front (cars and buses/trucks), bus operating conditions (run/idle), and door status (open/close) are monitored by analyzing the hard drives taken from the buses at the end of each week that recorded the video from closed circuit cameras. The processed hourly averages are then used to determine the trends and variations on a daily, monthly, and seasonal basis. One study has been found in the literature that has provided more details on the bus camera positions and real-time data monitoring methodology [42].

To make sure that the data collected was a quality one, Yes Plus monitors were calibrated each week since May 2007 for gaseous sensors. The Grimm 1.108 Dustmonitor 
instruments were regularly cleaned with canned air and the particulate filters $(47 \mathrm{~mm}$ Teflon) were frequently replaced at the end of three weeks to prevent clogging of inlets. It was made sure that the Grimm monitors were still under factory calibration and this ensured quality data from it. The Dusttrak monitors were zero checked and the nozzles were cleaned at the end of each week, and particulate filters replaced at the end of three weeks to obtain good quality data from the instruments. A couple of studies can be found in the literature that provided a detailed discussion on the calibration and maintenance procedures adopted by the researchers to ensure quality data were obtained from the instruments $[33,42]$.

\section{DATA COLLECTED AND DATA USED FOR TREND ANALYSIS}

The indoor air quality data were collected from the set of three instruments placed in each 500 series bus which ran on Route \#20. As the gaseous concentration instrument had to be sent back to the factory for updating the mother board in July 2007, there is no representative sample for that month in a ULSD bus. Both of the Grimm monitors were sent back for factory calibration during the months of July 2007 and August 2007 that resulted in no data being collected in ULSD bus in the month of July 2007. It was observed that the relative deviation was less than $2 \%$ for the total dust for the instruments from factory calibration. The dataset used for determining the trend analysis was representative of the selected route, selected bus, and having all the cameras in proper working condition. This yielded one year (April 2007 through March 2008) of quality data from Yes Plus instrument that is placed in the BD bus and 11 months (January 2007 through December 2007 except in July 2007 when it was sent to the factory) of quality data from the Yes Plus instrument placed in a ULSD bus. The Grimm instrument placed in the BD bus gave nine months of particle number concentrations (September 2006 - November 2006, January 2007 - May 2007 and September 2007) and 6 months of environmental data $\left(\mathrm{PM}_{1.0}, \mathrm{PM}_{2.5}\right.$ and $\mathrm{PM}_{10.0}$ - October 2007 through March 2008), while the instrument placed in the ULSD bus gave four months of environmental data (September 2007 through January 2008 excluding December) and four months of particle number concentrations (December 2006 through March 2007). The Dusttrak placed in BD bus gave three months of $\mathrm{PM}_{1.0}$ and four months of $\mathrm{PM}_{2.5}$ while the one placed in the ULSD bus gave four months of $\mathrm{PM}_{1.0}$ and five months of $\mathrm{PM}_{2.5}$. Since there is an overlap of the data collected between Grimm and Dusttrak, the readings monitored through Grimm are only used for analysis.

Since only 2 buses have been used for the study, a two sample t test was used to evaluate and compare the statistical significance of the hourly pollutant averages from the two buses on a monthly and seasonal basis. The different seasons in this study are defined as winter (January-March), spring (April-June), summer (July-September) and fall (OctoberDecember). The data were divided into these seasons to analyze the trends of the in-vehicle pollutants seasonally. The raw data were processed and classified into different seasons to study the seasonal variations. It should be noted that for monthly and seasonal comparison of gaseous pollutant levels, data collected during the three months (Jan., Feb., Mar.) and winter season should not be compared as they represent two different years (2007 winter (Jan. - Mar.) for ULSD bus and 2008 winter (Jan. - Mar.) for a BD bus). The same conditions apply when comparing particulate matter levels across different months and seasons from different years.

\section{RESULTS AND DISCUSSION}

This section presents the daily, monthly, and seasonal trends observed for different pollutant concentrations and a discussion on the possible factors that could have affected the variations is summarized. Different statistical parameters such as arithmetic mean or average (AM), standard deviation (SD), minimum (Min.), maximum (Max.), quartile 1 (Q1), quartile 3 (Q3), and coefficient of variance (CV) are computed for hourly average pollutant concentrations on a monthly and seasonal basis for each monitored in-vehicle pollutant. A two sample $t$ test is used to determine if the means of hourly average pollutant concentrations are significantly different or not for BD and ULSD buses for different months and seasons, and data that is representative of only the months and seasons of the same year during which both buses were tested simultaneously is used for the analysis. The authors did not consider the data collected from different months and seasons of different years when performing the two sample $t$ test as the driving conditions, traffic, and meteorological conditions change completely. The null hypothesis $\left(\mathrm{H}_{0}\right)$ is the means of hourly average pollutant concentration in both B20 and ULSD buses are same. The alternative hypothesis $\left(\mathrm{H}_{\mathrm{a}}\right)$ is the means of hourly average pollutant concentration in both B20 and ULSD buses are different. We reject the null hypothesis and accept the alternate hypothesis that difference between B20 and ULSD hourly average means is not zero and the difference is statistically significant if p-value $<0.05(\alpha)$. We accept the null hypothesis and reject the alternate hypothesis that difference between B20 and ULSD hourly average means is zero and the difference in hourly average means is not statistically significant if p-value $>0.05(\alpha)$. MINITAB $15^{\circledR}$ was used to perform this test.

$\mathrm{CO}_{2}$ Concentrations: Fig. (2) presents a comparison of $\mathrm{CO}_{2}$ levels in BD and ULSD buses on a monthly basis. It can be observed that the $\mathrm{CO}_{2}$ levels were found to peak between 8:00 am and 11:00 am while most of the people would be going to their work places and children going to schools. The $\mathrm{CO}_{2}$ levels decreased in the afternoon when there was a decrease in the number of passengers in the bus and a peak is again observed between 5:00 pm and 8:00 pm, the time at which most of the people would be returning home. After 8:00 pm the levels go down once again and another small spike in concentrations is observed in some cases when there is an increase in passenger ridership. The $\mathrm{CO}_{2}$ levels reached a daily maximum of $2100 \mathrm{ppm}$ in some days and quite frequently reached 1200 ppm - 1500 ppm during the peak hours. These higher concentration levels are generally observed during the peak hours and at traffic signal junctions when there are many vehicles in an idling position along with the bus. This observation was made from the video analysis.

Table 2 presents the summary of different statistical parameters obtained for $\mathrm{CO}_{2}$ pollutant in $\mathrm{BD}$ and ULSD buses 


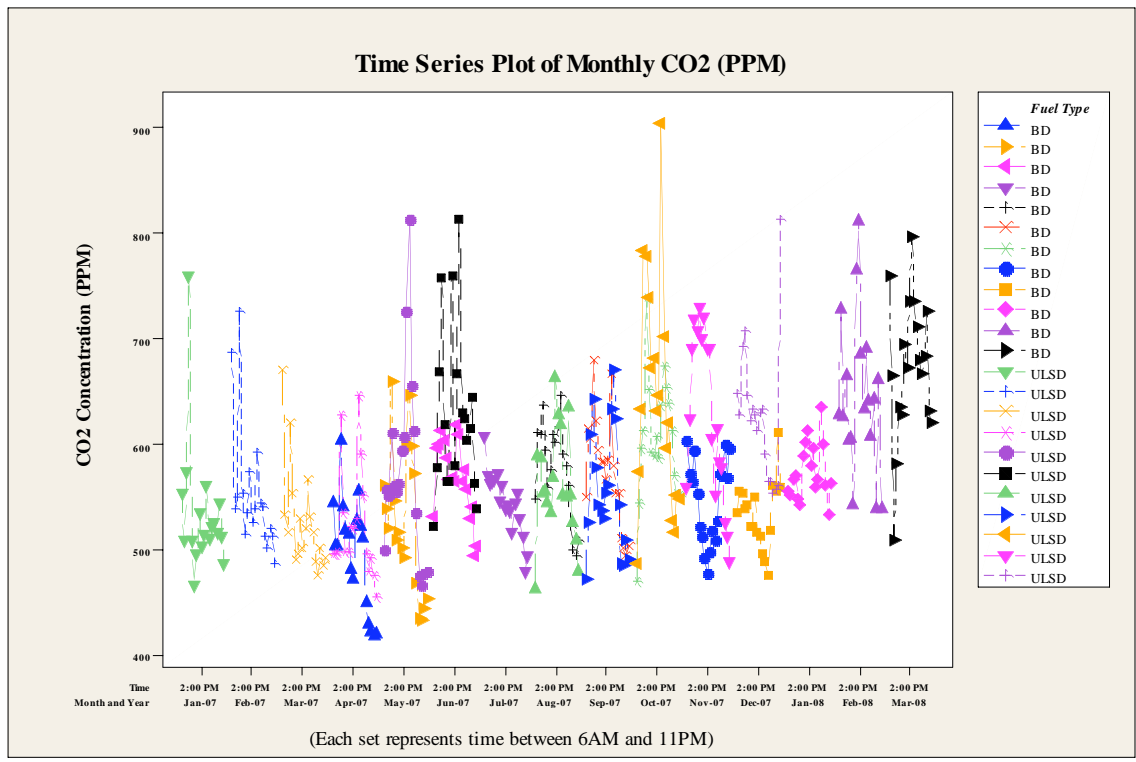

Fig. (2). Monthly $\mathrm{CO}_{2}$ concentration trends in BD and ULSD buses.

Table 2. Summary of Statistical Results for Monthly $\mathrm{CO}_{2}$ Levels in BD and ULSD Buses

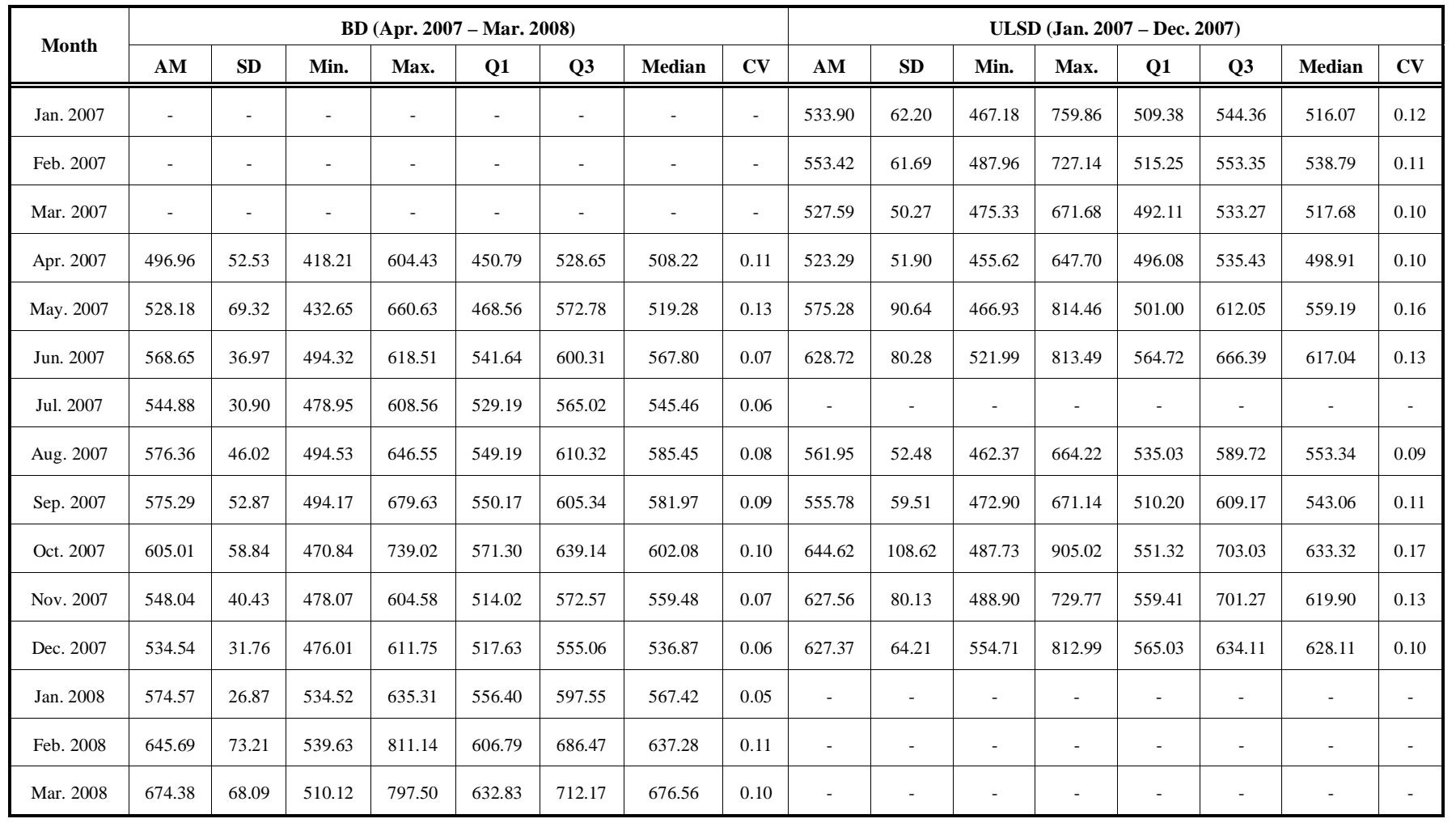

on a monthly basis. Two sample t test indicated that there is statistically significant difference between mean hourly averages of monthly $\mathrm{CO}_{2}$ pollutants in BD and ULSD buses ( $\mathrm{T}$ $=-4.54, \mathrm{P}=0.000)$. It was observed that the monthly $\mathrm{CO}_{2}$ levels in an ultra low sulfur diesel bus $(\mu=593.1 \mathrm{ppm})$ are statistically significantly higher compared to the monthly $\mathrm{CO}_{2}$ levels in a biodiesel bus $(\mu=554.1 \mathrm{ppm})$ for the months from April 2007 to December 2007 excluding July 2007. During these months, the passenger ridership was found to be similar irrespective of the bus as observed from the video footage. But, the numbers of lead vehicles are found to be higher in the case of a ULSD bus compared to a BD bus, except in the months of August 2007 and September 2007. This suggests that the monthly variations are mainly a result of the changes in vehicular traffic and is justified from the observation that $\mathrm{CO}_{2}$ levels are found to be higher in biodiesel buses in August 2007 and September 2007 as can be seen from Table 2 arithmetic means.

Fig. (3) presents the seasonal variation of $\mathrm{CO}_{2}$ pollutant in BD and ULSD buses and Table 3 presents the summary of 


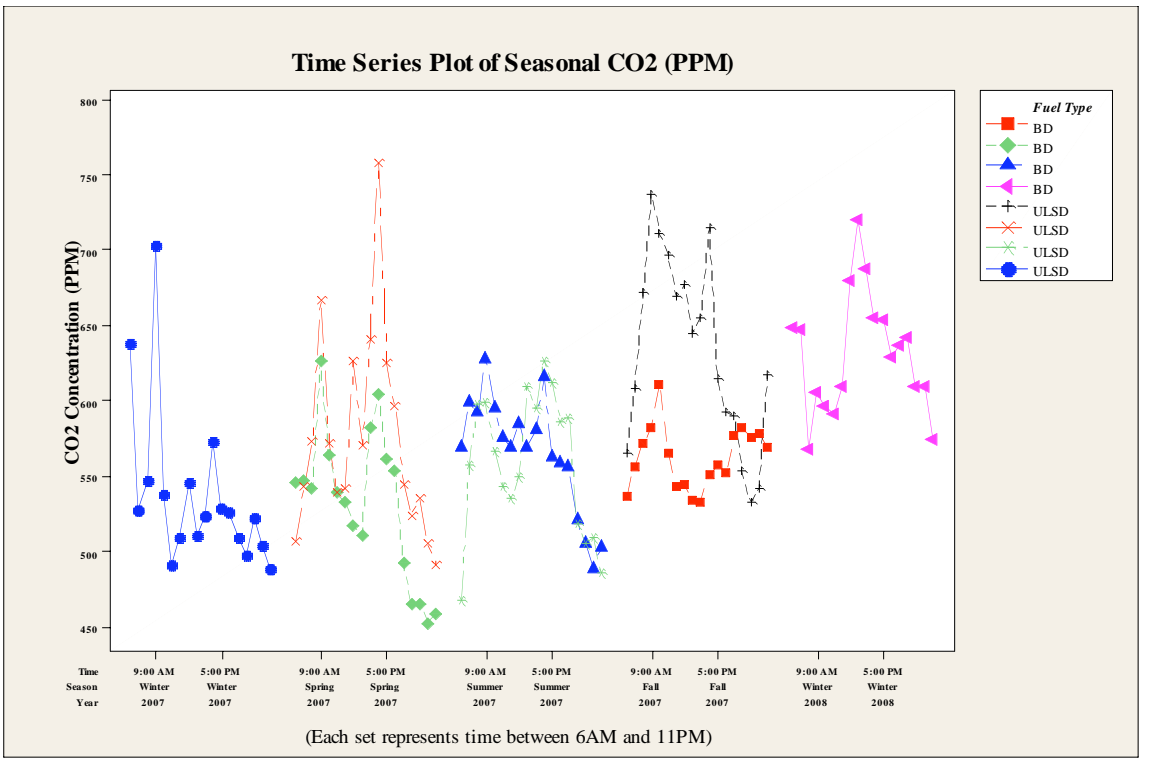

Fig. (3). Seasonal $\mathrm{CO}_{2}$ concentration trends in $\mathrm{BD}$ and ULSD buses.

Table 3. Summary of Statistical Results for Seasonal $\mathrm{CO}_{2}$ Levels in $\mathrm{BD}$ and ULSD Buses

\begin{tabular}{|c|c|c|c|c|c|c|c|c|c|c|c|c|c|c|c|c|}
\hline \multirow{2}{*}{ Season } & \multirow[b]{2}{*}{$\mathbf{A M}$} & \multicolumn{7}{|c|}{ BD (Spring 2007 - Winter 2008) } & & \multicolumn{7}{|c|}{ ULSD (Winter 2007 - Fall 2007) } \\
\hline & & SD & Min. & Max. & Q1 & Q3 & Median & $\mathrm{CV}$ & $\mathbf{A M}$ & SD & Min. & Max. & Q1 & Q3 & Median & CV \\
\hline $\begin{array}{c}\text { Winter } \\
2007\end{array}$ & - & - & - & - & - & - & - & - & 538.31 & 53.66 & 489.31 & 702.74 & 525.61 & 509.23 & 546.12 & 0.10 \\
\hline $\begin{array}{c}\text { Spring } \\
2007\end{array}$ & 531.26 & 49.92 & 452.50 & 626.45 & 492.32 & 561.89 & 540.28 & 0.09 & 575.76 & 67.31 & 491.56 & 758.55 & 557.70 & 535.22 & 625.47 & 0.12 \\
\hline $\begin{array}{c}\text { Summer } \\
2007\end{array}$ & 565.51 & 38.75 & 489.22 & 627.50 & 556.65 & 593.01 & 569.50 & 0.07 & 558.87 & 46.88 & 467.63 & 626.60 & 562.69 & 519.28 & 598.19 & 0.08 \\
\hline Fall 2007 & 562.53 & 20.73 & 532.82 & 611.61 & 544.34 & 575.70 & 561.73 & 0.04 & 633.18 & 62.77 & 533.57 & 737.42 & 631.16 & 589.69 & 672.60 & 0.10 \\
\hline $\begin{array}{c}\text { Winter } \\
2008\end{array}$ & 631.55 & 40.14 & 568.05 & 719.90 & 605.71 & 654.43 & 633.25 & 0.06 & - & - & - & - & - & - & - & - \\
\hline
\end{tabular}

statistical parameters associated with seasonal $\mathrm{CO}_{2}$ levels. Two sample $t$ test indicated that there is statistically significant difference between mean hourly averages of $\mathrm{CO}_{2}$ pollutants in BD and ULSD buses on a seasonal basis $(\mathrm{T}=-$ $3.40, \mathrm{P}=0.001)$. It was observed that the seasonal $\mathrm{CO}_{2}$ levels in an ultra low sulfur diesel bus $(\mu=589.3 \mathrm{ppm})$ are statistically significantly higher compared to the seasonal $\mathrm{CO}_{2}$ levels in a biodiesel bus $(\mu=553.1 \mathrm{ppm})$ for the seasons from spring 2007 to fall 2007. The Toledo area receives a fair amount of snowfall in the winter. Relatively higher $\mathrm{CO}_{2}$ levels are observed in a BD bus during the winter as compared to other seasons since the windows are kept in closed positions by the passengers to keep warm and there is insufficient air exchange to prevent pollutant buildup in the bus. This observation of keeping the windows closed during winter was made from the video analysis. However, lower levels of $\mathrm{CO}_{2}$ observed in a ULSD bus during winter are mainly a result of more ventilation. During the other seasons, windows are kept open for longer durations and the pollutant concentration buildup is mainly due to the penetration of outdoor $\mathrm{CO}_{2}$ emissions coming from vehicle exhaust and to some extent on passenger ridership. While the daily variation of carbon dioxide is due to a combination of passenger rider- ship, vehicular traffic, ventilation settings, and bus status; monthly and seasonal variations are caused mainly due to vehicular traffic and ventilation settings. It can be inferred that in-vehicle carbon dioxide levels are influenced by passenger ridership, ventilation settings, and vehicular traffic.

CO Concentrations: The monthly variation of $\mathrm{CO}$ levels in BD and ULSD buses with time can be observed from Fig. (4). The gradual increase in the $\mathrm{CO}$ levels in the morning might be due to the fact that there is more traffic as most people would be travelling to their work places and schools. $\mathrm{CO}$ levels decrease in the afternoon during which less traffic is observed and increases once again in the evening when people return from their work places and another peak is observed between 9:00 pm and 11:00 pm. The daily maximum concentrations reached $35 \mathrm{ppm}$ frequently and a maximum of $50 \mathrm{ppm}$ was observed during periods of heavy traffic.

Table 4 presents the summary of different statistical parameters obtained for $\mathrm{CO}$ in $\mathrm{BD}$ and ULSD buses on a monthly basis. Two sample $t$ test indicated that there is statistically significant difference between mean hourly aver- 


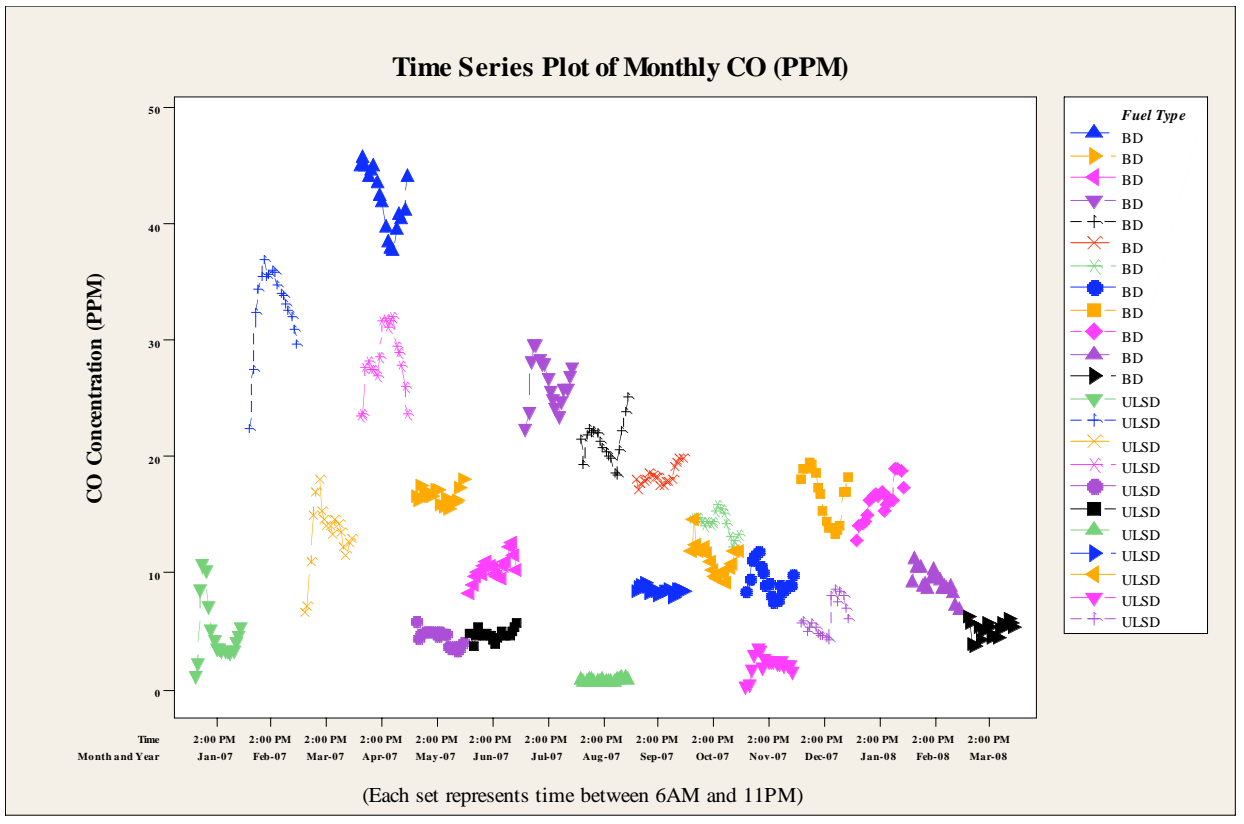

Fig. (4). Monthly CO concentration trends in BD and ULSD buses.

ages of monthly $\mathrm{CO}$ pollutant levels in BD and ULSD buses $(\mathrm{T}=9.71, \mathrm{P}=0.000)$. It was observed that the monthly $\mathrm{CO}$ levels in a biodiesel bus $(\mu=18.64 \mathrm{ppm})$ are statistically significantly higher compared to the monthly $\mathrm{CO}$ levels observed in ultra low sulfur diesel bus $(\mu=8.31 \mathrm{ppm})$ for the months from April 2007 to December 2007 excluding July 2007. Higher concentrations that are observed for a biodiesel bus in August 2007 and September 2007 could be due to the higher number of lead vehicles. For other months, even though the numbers of lead vehicles are higher for a ULSD bus, relatively lower concentrations were recorded. This could possibly be due to the reason that not much ventilation is provided for ULSD bus compared to the biodiesel bus. This shows the monthly CO levels to be mainly influenced by the vehicular traffic and ventilation settings.

Fig. (5) presents the seasonal variation of $\mathrm{CO}$ in $\mathrm{BD}$ and ULSD buses while Table $\mathbf{5}$ presents the summary of statistical parameters associated with seasonal CO levels. Two sample $t$ test indicated there is statistically significant difference between mean hourly averages of seasonal $\mathrm{CO}$ concentrations in $\mathrm{BD}$ and ULSD buses $(\mathrm{T}=14.83, \mathrm{P}=0.000)$. It was observed that the seasonal CO levels in an ultra low sulfur diesel bus ( $\mu=7.31 \mathrm{ppm}$ ) are statistically significantly lower compared to the seasonal $\mathrm{CO}$ levels in a biodiesel bus $(\mu=19.50 \mathrm{ppm})$ for the seasons from spring 2007 to fall 2007 . The relatively lower CO levels in winter in a biodiesel bus might be due to reduced ventilation caused by the closing of windows by passengers to keep comfortable. For other seasons, $\mathrm{CO}$ levels varied with varying vehicular traffic and ventilation settings. Higher $\mathrm{CO}$ levels in a $\mathrm{BD}$ bus in summer 2007 is a result of higher lead vehicular traffic while higher CO levels in spring 2007 and fall 2007 in a BD bus is a result of more ventilation with less lead vehicular traffic as compared to the case of the ULSD bus. In an ultra low sulfur diesel bus, higher concentrations were observed in winter 2007 followed by spring 2007, fall 2007, and summer 2007 .
It was observed that a ULSD bus produced more CO emissions compared to the biodiesel bus [49]. During the winter period, since there is heavy snow on road, the buses move more slowly during which there is a possibility of more self intrusion of the $\mathrm{CO}$ pollutant from the bus exhaust pipe even for less ventilation. The $\mathrm{CO}$ pollutant levels observed in ULSD bus during other seasons changed along with varying vehicular traffic. One can observe the winter $\mathrm{CO}$ levels in $\mathrm{BD}$ and ULSD buses to be exhibiting different trends from Fig. (5) when both the bus moves slowly due to snow conditions even though one would expect to see similar trends. This is a consequence of collecting data for winter during two different years where the driving conditions and the severity of the winter change completely. Also, the observation that ULSD bus produced more $\mathrm{CO}$ emissions as compared to BD bus [49] justifies that relatively higher self exhaust characteristic playing a major role in obtaining higher $\mathrm{CO}$ levels in ULSD bus during winter 2007 as compared to the CO levels in BD bus during winter 2008. The daily, monthly, and seasonal variations of $\mathrm{CO}$ are mainly caused by the combination of vehicular traffic and ventilation settings, while speed of the vehicle could have an effect to some extent.

$\mathrm{SO}_{2}$ Concentrations: Fig. (6) presents the monthly variation of $\mathrm{SO}_{2}$ concentrations in $\mathrm{BD}$ and ULSD buses. All the data values less than the sensor resolution were removed from the analysis. $\mathrm{SO}_{2}$ concentrations were found to be higher during the morning peak hours when vehicular traffic is more. $\mathrm{SO}_{2}$ concentrations then either remained the same or decreased in the afternoon and once again increased during the evening peak hours and in the late night in proportion to the vehicular traffic. The $\mathrm{SO}_{2}$ levels reached a daily maximum of $2 \mathrm{ppm}$ in some days and quite frequently reached 0.7 ppm.

Table 6 presents the summary of different statistical parameters obtained for $\mathrm{SO}_{2}$ in $\mathrm{BD}$ and ULSD buses on a 
Table 4. Summary of Statistical Results for Monthly CO Levels in BD and ULSD Buses

\begin{tabular}{|c|c|c|c|c|c|c|c|c|c|c|c|c|c|c|c|c|}
\hline \multirow{2}{*}{ Month } & \multicolumn{8}{|c|}{ BD (Apr. 2007 - Mar. 2008) } & \multicolumn{8}{|c|}{ ULSD (Jan. 2007 - Dec. 2007) } \\
\hline & $\mathbf{A M}$ & SD & Min. & Max. & Q1 & Q3 & Median & $\mathbf{C V}$ & $\mathbf{A M}$ & SD & Min. & Max. & Q1 & Q3 & Median & $\mathbf{C V}$ \\
\hline Jan. 2007 & - & - & - & - & - & - & - & - & 4.90 & 2.64 & 1.32 & 10.76 & 3.38 & 5.44 & 3.83 & 0.54 \\
\hline Feb. 2007 & - & - & - & - & - & - & - & - & 32.96 & 3.56 & 22.44 & 36.91 & 32.13 & 35.47 & 33.95 & 0.11 \\
\hline Mar. 2007 & - & - & - & - & - & - & - & - & 13.27 & 2.85 & 6.73 & 18.03 & 12.31 & 14.72 & 13.80 & 0.21 \\
\hline Apr. 2007 & 41.99 & 2.68 & 37.60 & 45.64 & 39.58 & 44.59 & 42.13 & 0.06 & 28.25 & 2.78 & 23.55 & 32.05 & 26.91 & 31.13 & 28.04 & 0.10 \\
\hline May. 2007 & 16.65 & 0.70 & 15.48 & 18.03 & 16.10 & 17.21 & 16.67 & 0.04 & 4.55 & 0.68 & 3.41 & 5.87 & 3.79 & 4.99 & 4.82 & 0.15 \\
\hline Jun. 2007 & 10.43 & 1.07 & 8.33 & 12.70 & 9.77 & 10.96 & 10.38 & 0.10 & 4.75 & 0.47 & 3.86 & 5.74 & 4.60 & 5.04 & 4.75 & 0.10 \\
\hline Jul. 2007 & 26.41 & 2.12 & 22.41 & 29.72 & 24.84 & 28.04 & 26.37 & 0.08 & - & - & - & - & - & - & - & - \\
\hline Aug. 2007 & 21.28 & 1.74 & 18.47 & 25.19 & 20.05 & 22.17 & 21.40 & 0.08 & 0.81 & 0.09 & 0.71 & 1.07 & 0.75 & 0.83 & 0.78 & 0.12 \\
\hline Sep. 2007 & 18.34 & 0.77 & 17.21 & 19.86 & 17.95 & 18.58 & 18.14 & 0.04 & 8.55 & 0.31 & 7.98 & 9.18 & 8.37 & 8.61 & 8.52 & 0.04 \\
\hline Oct. 2007 & 14.39 & 0.97 & 12.24 & 15.92 & 14.05 & 14.88 & 14.46 & 0.07 & 11.26 & 1.33 & 9.28 & 14.65 & 10.08 & 11.95 & 11.41 & 0.12 \\
\hline Nov. 2007 & 9.39 & 1.26 & 7.61 & 11.95 & 8.40 & 10.14 & 9.09 & 0.13 & 2.20 & 0.82 & 0.32 & 3.55 & 1.99 & 2.47 & 2.32 & 0.37 \\
\hline Dec. 2007 & 16.63 & 2.21 & 13.44 & 19.62 & 14.18 & 18.63 & 16.98 & 0.13 & 6.13 & 1.50 & 4.33 & 8.66 & 4.91 & 7.06 & 5.77 & 0.24 \\
\hline Jan. 2008 & 16.23 & 1.74 & 12.79 & 19.08 & 15.08 & 17.01 & 16.34 & 0.11 & - & - & - & - & - & - & - & - \\
\hline Feb. 2008 & 9.13 & 1.10 & 6.84 & 11.26 & 8.65 & 9.63 & 9.00 & 0.12 & - & - & - & - & - & - & - & - \\
\hline Mar. 2008 & 5.19 & 0.73 & 3.85 & 6.38 & 4.54 & 5.67 & 5.38 & 0.14 & - & - & - & - & - & - & - & - \\
\hline
\end{tabular}

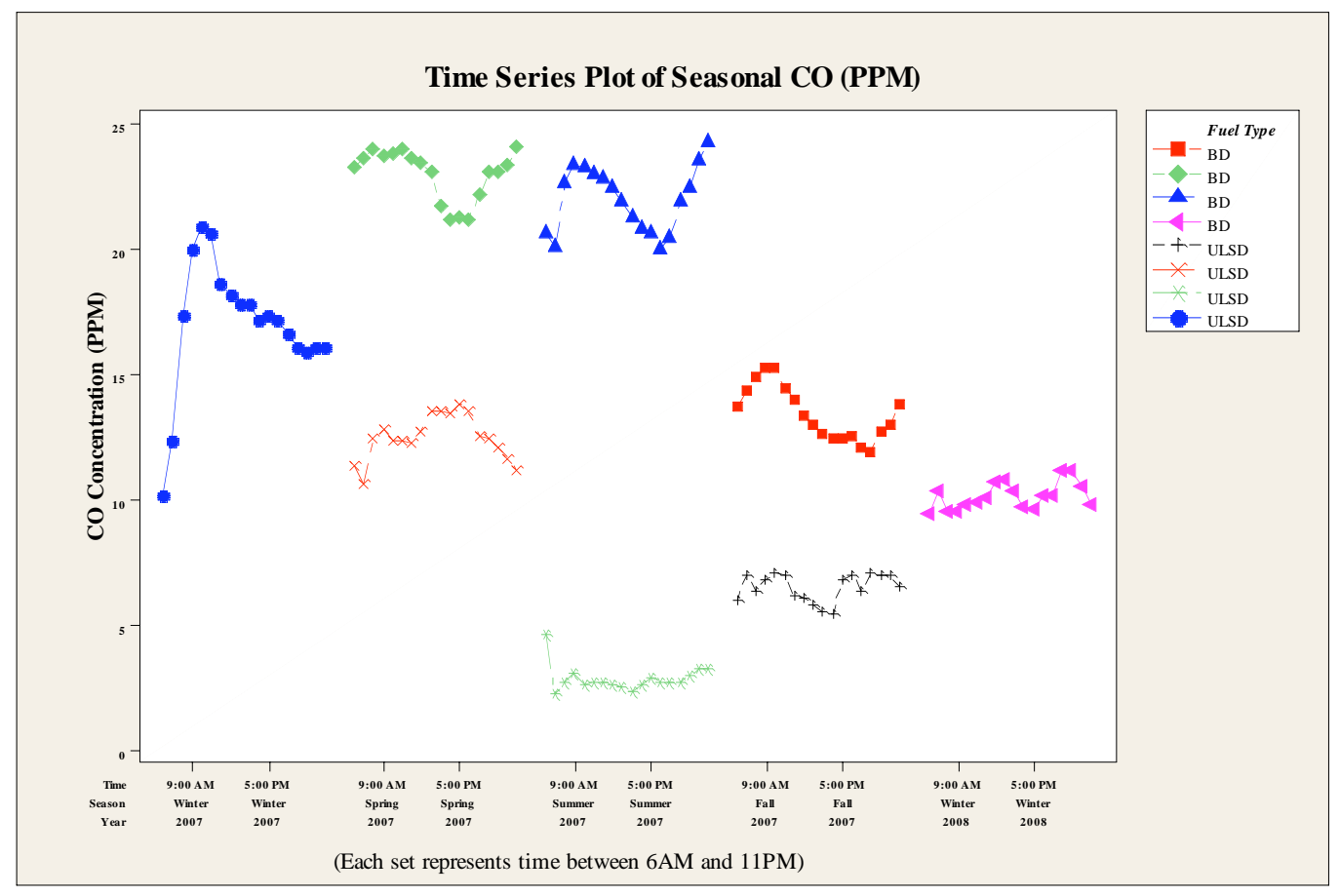

Fig. (5). Seasonal CO concentration trends in BD and ULSD buses. 
Table 5. Summary of Statistical Results for Seasonal CO Levels in BD and ULSD Buses

\begin{tabular}{|c|c|c|c|c|c|c|c|c|c|c|c|c|c|c|c|c|}
\hline \multirow{2}{*}{ Season } & \multicolumn{8}{|c|}{ BD (Spring 2007 - Winter 2008) } & \multicolumn{8}{|c|}{ ULSD (Winter 2007 - Fall 2007) } \\
\hline & $\mathbf{A M}$ & SD & Min. & Max. & Q1 & Q3 & Median & $\mathrm{CV}$ & $\mathbf{A M}$ & SD & Min. & Max. & Q1 & Q3 & Median & $\mathbf{C V}$ \\
\hline $\begin{array}{l}\text { Winter } \\
2007\end{array}$ & - & - & - & - & - & - & - & - & 17.04 & 2.61 & 10.16 & 20.92 & 16.11 & 18.20 & 17.30 & 0.15 \\
\hline $\begin{array}{l}\text { Spring } \\
2007\end{array}$ & 23.02 & 1.01 & 21.24 & 24.11 & 22.18 & 23.72 & 23.35 & 0.04 & 12.52 & 0.89 & 10.68 & 13.85 & 12.11 & 13.49 & 12.47 & 0.07 \\
\hline $\begin{array}{c}\text { Summer } \\
2007\end{array}$ & 22.01 & 1.31 & 20.02 & 24.26 & 20.69 & 23.06 & 22.22 & 0.06 & 2.88 & 0.51 & 2.32 & 4.62 & 2.65 & 3.01 & 2.75 & 0.18 \\
\hline Fall 2007 & 13.47 & 1.08 & 11.97 & 15.33 & 12.59 & 14.43 & 13.20 & 0.08 & 6.53 & 0.55 & 5.48 & 7.09 & 6.13 & 7.02 & 6.69 & 0.08 \\
\hline $\begin{array}{c}\text { Winter } \\
2008\end{array}$ & 10.18 & 0.54 & 9.46 & 11.18 & 9.78 & 10.35 & 10.15 & 0.05 & - & - & - & - & - & - & - & - \\
\hline
\end{tabular}

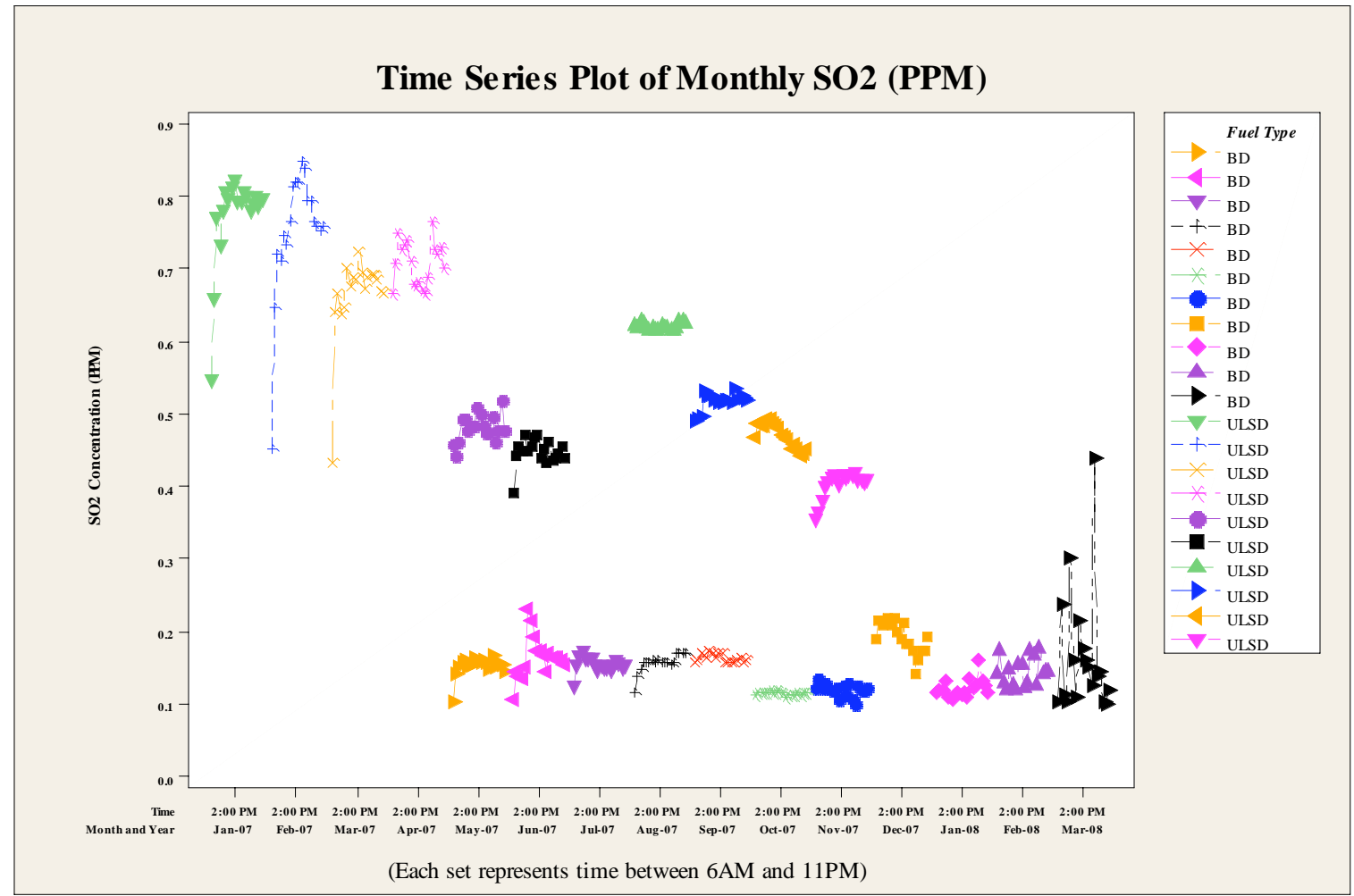

Fig. (6). Monthly $\mathrm{SO}_{2}$ concentration trends in $\mathrm{BD}$ and ULSD buses.

monthly basis. Two sample t test indicated that there is statistically significant difference between mean hourly averages of monthly $\mathrm{SO}_{2}$ pollutant levels in $\mathrm{BD}$ and ULSD buses $(\mathrm{T}=-48.61, \mathrm{P}=0.000)$. It was observed that monthly $\mathrm{SO}_{2}$ levels in an ultra low sulfur diesel bus $(\mu=0.49 \mathrm{ppm})$ are statistically significantly higher compared to the $\mathrm{SO}_{2}$ levels observed in a biodiesel bus $(\mu=0.15 \mathrm{ppm})$ for the months during which data were collected simultaneously from both the buses. The higher $\mathrm{SO}_{2}$ concentration levels in an ultra low sulfur diesel bus could be a result of more penetration of $\mathrm{SO}_{2}$ exhaust emissions from the higher lead vehicular traffic with less ventilation compared to the biodiesel bus case where the lead vehicular traffic is relatively less with more ventilation. This observation was observed from the video analysis.
Fig. (7) presents the seasonal variation of $\mathrm{SO}_{2}$ concentrations in BD and ULSD buses and Table 7 presents the summary of statistical parameters associated with seasonal $\mathrm{SO}_{2}$ levels. Two sample t test indicated that there is statistically significant difference between mean hourly averages of seasonal $\mathrm{SO}_{2}$ pollutant levels in $\mathrm{BD}$ and ULSD buses $(\mathrm{T}=$ $44.07, \mathrm{P}=0.000)$. It was observed that seasonal $\mathrm{SO}_{2}$ levels in an ultra low sulfur diesel bus $(\mu=0.52 \mathrm{ppm})$ are statistically significantly higher compared to the seasonal $\mathrm{SO}_{2}$ levels observed in a biodiesel bus $(\mu=0.15 \mathrm{ppm})$ for the seasons from spring 2007 to fall 2007. Relatively higher $\mathrm{SO}_{2}$ levels are observed in winter 2007 for ULSD bus compared to other seasons. This could be due to more infiltration of sulfur dioxide emissions coming from the slow moving traf- 
Table 6. Summary of Statistical Results for Monthly $\mathrm{SO}_{2}$ Levels in BD and ULSD Buses

\begin{tabular}{|c|c|c|c|c|c|c|c|c|c|c|c|c|c|c|c|c|}
\hline \multirow{2}{*}{ Month } & \multicolumn{8}{|c|}{ BD (Apr. 2007 - Mar. 2008) } & \multicolumn{8}{|c|}{ ULSD (Jan. 2007 - Dec. 2007) } \\
\hline & $\mathbf{A M}$ & SD & Min. & Max. & Q1 & Q3 & Median & CV & $\mathbf{A M}$ & SD & Min. & Max. & Q1 & Q3 & Median & CV \\
\hline Jan. 2007 & - & - & - & - & - & - & - & - & 0.77 & 0.07 & 0.55 & 0.82 & 0.78 & 0.80 & 0.79 & 0.09 \\
\hline Feb. 2007 & - & - & - & - & - & - & - & - & 0.75 & 0.09 & 0.45 & 0.85 & 0.73 & 0.81 & 0.76 & 0.12 \\
\hline Mar. 2007 & - & - & - & - & - & - & - & - & 0.66 & 0.06 & 0.43 & 0.72 & 0.66 & 0.69 & 0.68 & 0.09 \\
\hline Apr. 2007 & - & - & - & - & - & - & - & - & 0.71 & 0.03 & 0.67 & 0.77 & 0.68 & 0.73 & 0.71 & 0.04 \\
\hline May. 2007 & 0.15 & 0.02 & 0.10 & 0.17 & 0.15 & 0.16 & 0.16 & 0.10 & 0.48 & 0.02 & 0.44 & 0.52 & 0.47 & 0.49 & 0.48 & 0.04 \\
\hline Jun. 2007 & 0.16 & 0.03 & 0.11 & 0.23 & 0.14 & 0.17 & 0.16 & 0.18 & 0.45 & 0.02 & 0.39 & 0.47 & 0.44 & 0.46 & 0.45 & 0.04 \\
\hline Jul. 2007 & 0.15 & 0.01 & 0.13 & 0.17 & 0.15 & 0.16 & 0.15 & 0.06 & - & - & - & - & - & - & - & - \\
\hline Aug. 2007 & 0.16 & 0.01 & 0.12 & 0.17 & 0.16 & 0.16 & 0.16 & 0.08 & 0.62 & 0.00 & 0.62 & 0.63 & 0.62 & 0.62 & 0.62 & 0.01 \\
\hline Sep. 2007 & 0.16 & 0.00 & 0.16 & 0.17 & 0.16 & 0.17 & 0.16 & 0.03 & 0.52 & 0.01 & 0.49 & 0.54 & 0.52 & 0.52 & 0.52 & 0.02 \\
\hline Oct. 2007 & 0.12 & 0.01 & 0.11 & 0.12 & 0.11 & 0.12 & 0.12 & 0.04 & 0.47 & 0.02 & 0.44 & 0.49 & 0.45 & 0.48 & 0.47 & 0.03 \\
\hline Nov. 2007 & 0.12 & 0.01 & 0.10 & 0.14 & 0.12 & 0.13 & 0.12 & 0.09 & 0.41 & 0.02 & 0.36 & 0.42 & 0.40 & 0.41 & 0.41 & 0.04 \\
\hline Dec. 2007 & 0.19 & 0.02 & 0.14 & 0.22 & 0.17 & 0.21 & 0.19 & 0.12 & - & - & - & - & - & - & - & - \\
\hline Jan. 2008 & 0.12 & 0.01 & 0.11 & 0.16 & 0.11 & 0.13 & 0.12 & 0.10 & - & - & - & - & - & - & - & - \\
\hline Feb. 2008 & 0.14 & 0.02 & 0.12 & 0.18 & 0.12 & 0.16 & 0.14 & 0.14 & - & - & - & - & - & - & - & - \\
\hline Mar. 2008 & 0.17 & 0.09 & 0.10 & 0.44 & 0.11 & 0.16 & 0.14 & 0.53 & - & - & - & - & - & - & - & - \\
\hline
\end{tabular}

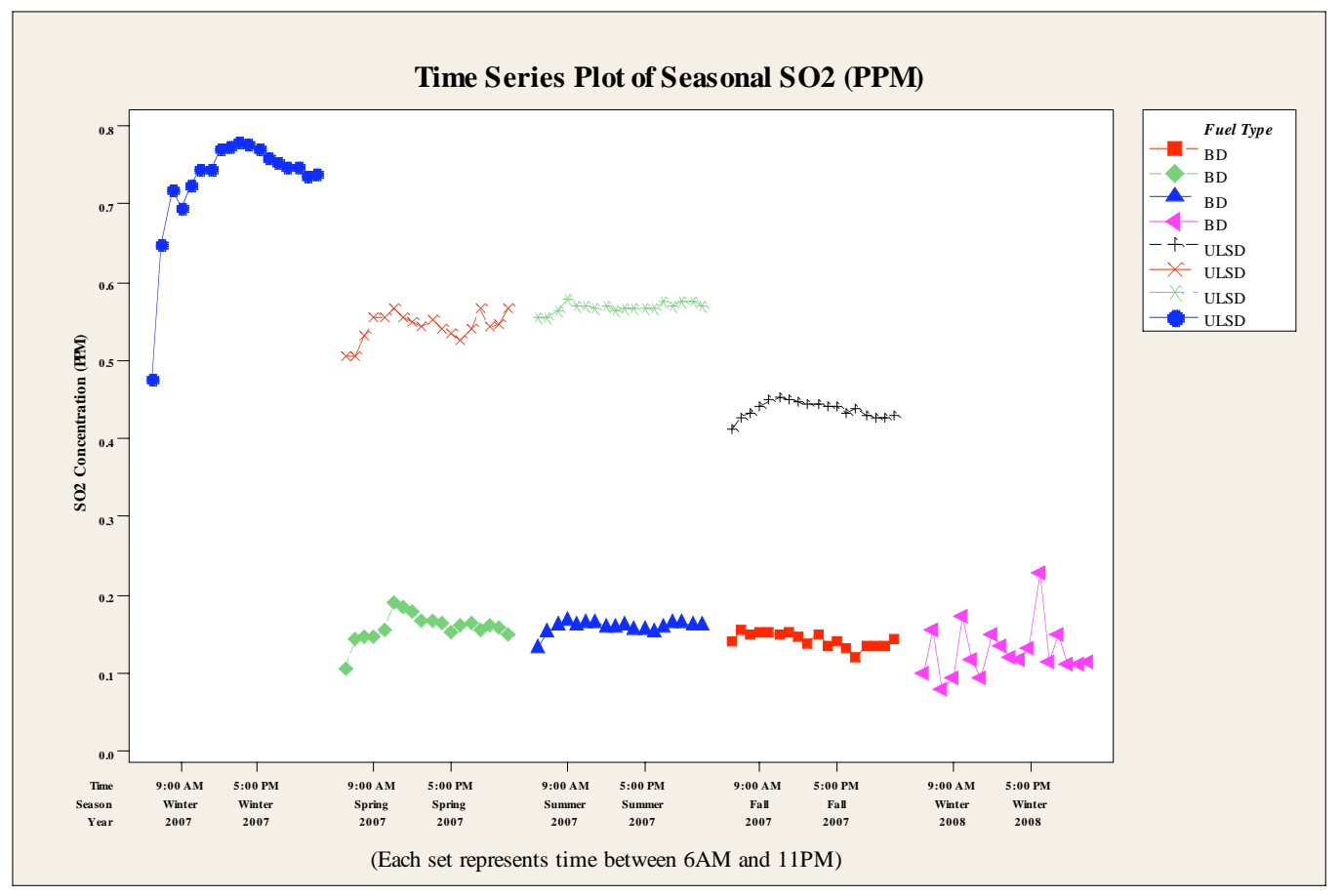

Fig. (7). Seasonal $\mathrm{SO}_{2}$ concentration trends in $\mathrm{BD}$ and ULSD buses. 
Table 7. Summary of Statistical Results for Seasonal $\mathrm{SO}_{2}$ Levels in BD and ULSD Buses

\begin{tabular}{|c|c|c|c|c|c|c|c|c|c|c|c|c|c|c|c|c|}
\hline \multirow{2}{*}{ Season } & \multicolumn{8}{|c|}{ BD (Spring 2007 - Winter 2008) } & \multicolumn{8}{|c|}{ ULSD (Winter 2007 - Fall 2007) } \\
\hline & $\mathbf{A M}$ & SD & Min. & Max. & Q1 & Q3 & Median & $\mathrm{CV}$ & $\mathbf{A M}$ & SD & Min. & Max. & Q1 & Q3 & Median & CV \\
\hline Winter 2007 & - & - & - & - & - & - & - & - & 0.73 & 0.07 & 0.48 & 0.78 & 0.73 & 0.77 & 0.75 & 0.10 \\
\hline Spring 2007 & 0.16 & 0.02 & 0.11 & 0.19 & 0.15 & 0.17 & 0.16 & 0.11 & 0.55 & 0.02 & 0.51 & 0.57 & 0.54 & 0.56 & 0.55 & 0.03 \\
\hline Summer 2007 & 0.16 & 0.01 & 0.13 & 0.17 & 0.16 & 0.16 & 0.16 & 0.06 & 0.57 & 0.01 & 0.55 & 0.58 & 0.57 & 0.57 & 0.57 & 0.01 \\
\hline Fall 2007 & 0.14 & 0.01 & 0.12 & 0.16 & 0.14 & 0.15 & 0.14 & 0.07 & 0.44 & 0.01 & 0.41 & 0.45 & 0.43 & 0.44 & 0.44 & 0.02 \\
\hline Winter 2008 & 0.13 & 0.04 & 0.08 & 0.23 & 0.11 & 0.13 & 0.12 & 0.28 & - & - & - & - & - & - & - & - \\
\hline
\end{tabular}

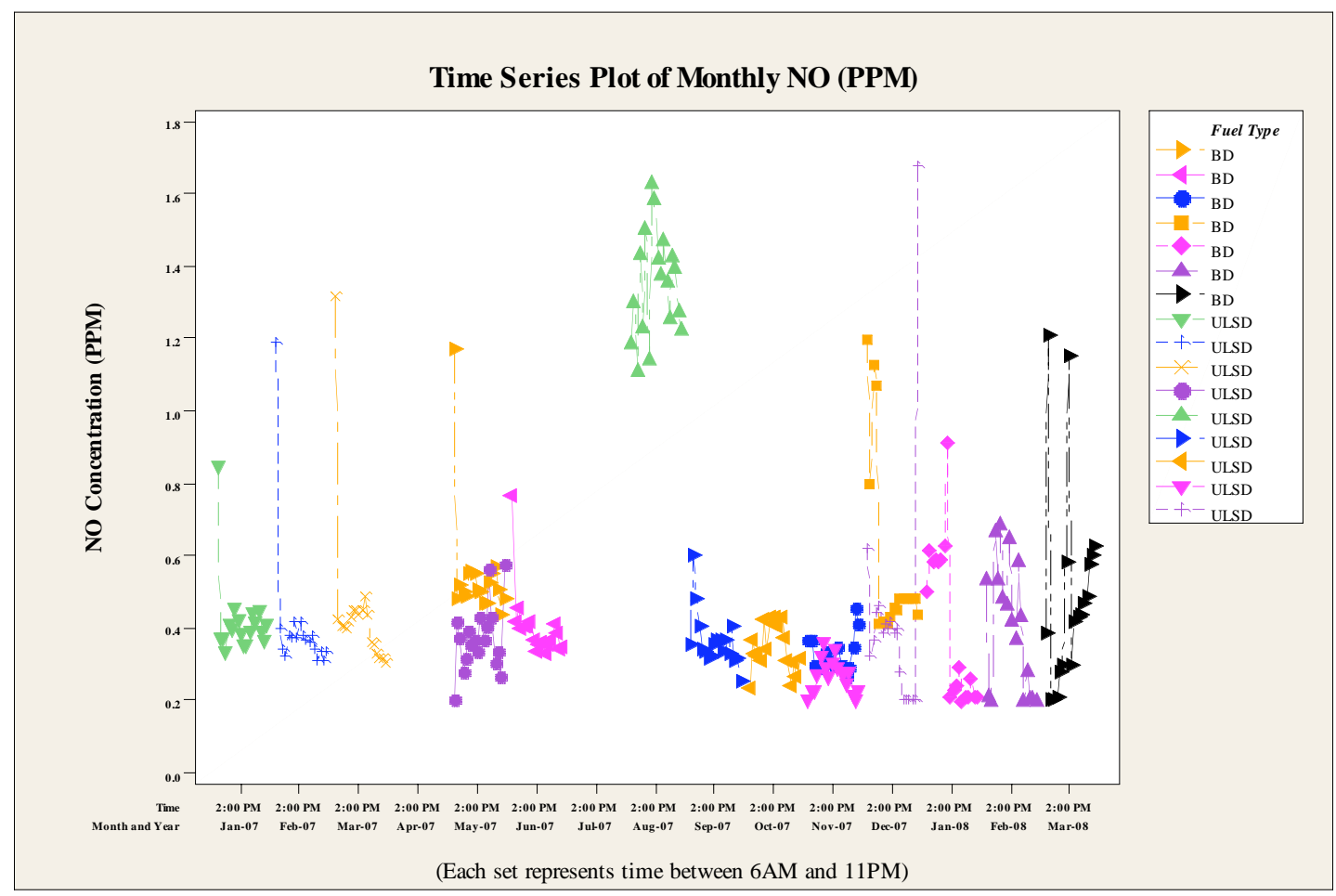

Fig. (8). Monthly NO concentration trends in BD and ULSD buses.

fic as well as higher self intrusion due to icy roads. The sulfur dioxide concentrations for other seasons varied with varying vehicular traffic and ventilation settings. Higher seasonal $\mathrm{SO}_{2}$ levels observed in ULSD bus during spring 2007 and fall 2007 are a result of higher vehicular traffic with less ventilation while higher $\mathrm{SO}_{2}$ concentrations observed during summer 2007 are a result of less vehicular traffic with more ventilation when compared to the case of a BD bus in respective seasons. The daily, monthly, and seasonal variations of $\mathrm{SO}_{2}$ are mainly caused by the combination of vehicular traffic, ventilation settings, and vehicle speed to an extent.

NO Concentrations: Fig. (8) presents the monthly variation of NO in BD and ULSD buses. All the data values less than the sensor resolution were removed from the analysis. A peak is obtained early in the morning between 6:00 am and 8:00 am. The concentration levels then decrease and the second spike is observed around 11:00 am. The concentrations decrease further in the afternoon and an upward trend is observed between 4:00 pm and 8:00 pm. The NO levels reached a daily maximum of $3 \mathrm{ppm}$ in some days and quite frequently reached $2 \mathrm{ppm}$.

Table 8 presents the summary of different statistical parameters obtained for $\mathrm{NO}$ in BD and ULSD buses on a monthly basis. Two sample t test indicated that there is statistically significant difference between mean hourly averages of monthly NO pollutant levels in BD and ULSD buses $(\mathrm{T}=3.26, \mathrm{P}=0.002)$. It was observed that monthly NO levels in an ultra low sulfur diesel bus $(\mu=0.36 \mathrm{ppm})$ are statistically significantly lower compared to the monthly NO levels observed in a biodiesel bus $(\mu=0.49 \mathrm{ppm})$ for the months during which data were collected simultaneously from both the buses. Nitric oxide levels are found to be relatively higher in a BD bus as compared to a ULSD bus in certain months, even though the number of lead vehicles for ULSD bus are higher. Thus, it can be inferred that ventila- 
Table 8. Summary of Statistical Results for Monthly NO Levels in BD and ULSD Buses

\begin{tabular}{|c|c|c|c|c|c|c|c|c|c|c|c|c|c|c|c|c|}
\hline \multirow{2}{*}{ Month } & \multicolumn{8}{|c|}{ BD (Apr. 2007 - Mar. 2008) } & \multicolumn{8}{|c|}{ ULSD (Jan. 2007 - Dec. 2007) } \\
\hline & AM & SD & Min. & Max. & Q1 & Q3 & Median & $\mathbf{C V}$ & AM & SD & Min. & Max. & Q1 & Q3 & Median & CV \\
\hline Feb. 2007 & - & - & - & - & - & - & - & - & 0.41 & 0.20 & 0.31 & 1.19 & 0.34 & 0.38 & 0.37 & 0.48 \\
\hline Apr. 2007 & - & - & - & - & - & - & - & - & - & - & - & - & - & - & - & - \\
\hline May. 2007 & 0.55 & 0.16 & 0.44 & 1.17 & 0.48 & 0.55 & 0.51 & 0.29 & 0.37 & 0.09 & 0.20 & 0.58 & 0.32 & 0.42 & 0.37 & 0.25 \\
\hline Jun. 2007 & 0.40 & 0.10 & 0.33 & 0.76 & 0.35 & 0.41 & 0.38 & 0.24 & - & - & - & - & - & - & - & - \\
\hline Oct. 2007 & - & - & - & - & - & - & - & - & 0.35 & 0.07 & 0.24 & 0.44 & 0.31 & 0.42 & 0.34 & 0.19 \\
\hline Nov. 2007 & 0.33 & 0.05 & 0.27 & 0.46 & 0.30 & 0.35 & 0.31 & 0.15 & 0.27 & 0.05 & 0.20 & 0.36 & 0.23 & 0.30 & 0.28 & 0.18 \\
\hline Dec. 2007 & 0.58 & 0.27 & 0.41 & 1.20 & 0.43 & 0.48 & 0.48 & 0.46 & 0.42 & 0.33 & 0.20 & 1.68 & 0.20 & 0.41 & 0.39 & 0.79 \\
\hline Jan. 2008 & 0.40 & 0.22 & 0.20 & 0.91 & 0.21 & 0.59 & 0.28 & 0.54 & - & - & - & - & - & - & - & - \\
\hline Feb. 2008 & 0.41 & 0.18 & 0.20 & 0.68 & 0.21 & 0.53 & 0.43 & 0.44 & - & - & - & - & - & - & - & - \\
\hline Mar. 2008 & 0.49 & 0.29 & 0.20 & 1.21 & 0.30 & 0.58 & 0.44 & 0.58 & - & - & - & - & - & - & - & - \\
\hline
\end{tabular}

tion settings have played a major role influencing daily and monthly in-vehicle NO levels along with vehicular traffic.

Fig. (9) presents the seasonal variation of NO concentrations in $\mathrm{BD}$ and ULSD buses and Table 9 presents the summary of statistical parameters associated with seasonal NO levels. Two sample $t$ test indicated that there is statistically significant difference between mean hourly averages of seasonal NO pollutant levels in BD and ULSD buses $(\mathrm{T}=3.83$, $\mathrm{P}=0.000)$. It was observed that seasonal NO levels in an ultra low sulfur diesel bus $(\mu=0.36 \mathrm{ppm})$ are statistically significantly lower compared to the seasonal $\mathrm{SO}_{2}$ levels observed in a biodiesel bus ( $\mu=0.47 \mathrm{ppm})$ for spring 2007 and fall 2007 seasons. Relatively higher NO levels are observed in a BD bus for spring 2007 and fall 2007 indicating higher penetration of outdoor NO indoors even for less number of lead vehicles with more ventilation, that resulted in more accumulation of in-vehicle NO levels as compared to the ULSD bus having more number of lead vehicles and less ventilation. NO levels are observed to be the maximum in ULSD bus during summer 2007. NO emissions were found to be higher for ULSD buses as compared to BD buses [50]. Hence, higher vehicular self pollution even for less ventilation in addition to penetration of NO exhaust emissions from lead vehicles could have contributed to high vehicular NO levels in summer 2007. The daily and monthly variations of $\mathrm{NO}$ are mainly a result of varying traffic and ventilation settings while seasonal variation is a result of change in ventilation settings and vehicle exhaust emissions.
PM Concentrations: Particulate matter $\left(\mathrm{PM}_{1.0}, \mathrm{PM}_{2.5}\right.$, and $\left.\mathrm{PM}_{10.0}\right)$ monthly and seasonal concentration trends can be observed from Figs. ((10) through 12) in BD and ULSD buses. The particulate matter levels were found to be mainly influenced by ambient $\mathrm{PM}_{2.5}$ concentrations; therefore, repetitive trends are not observed. The particulate matter levels were found to be higher during the early hours, around 6:00 am when the bus leaves the garage where there are a lot of buses kept in idling position and the concentrations decrease as the bus goes out on the run till 8:00 am. The concentrations then increased during the peak hours and remained high until noon. The concentrations then decreased in the afternoon and again increased during the evening peak hours. Some spikes are observed during the night whenever there is an increase in the number of trucks and buses ahead of the test bus. Particulate matter levels are also found to be higher when the test bus reaches the garage where many other buses would be in idling condition. The $\mathrm{PM}_{10.0}, \mathrm{PM}_{2.5}$, and $\mathrm{PM}_{1_{3} 0}$ levels reached a daily maximum of $200 \mu \mathrm{g} / \mathrm{m}^{3}, 80 \mu \mathrm{g} / \mathrm{m}^{3}$, and $60 \mu \mathrm{g} / \mathrm{m}^{3}$ in some days and quite frequently reached 120 $\mu \mathrm{g} / \mathrm{m}^{3}, 60 \mu \mathrm{g} / \mathrm{m}^{3}$, and $40 \mu \mathrm{g} / \mathrm{m}^{3}$ respectively.

Table 10 presents the summary of different statistical parameters obtained for $\mathrm{PM}_{1.0}$ concentrations in $\mathrm{BD}$ and ULSD buses on a monthly basis. Two sample t test indicated that there is statistically no significant difference between mean hourly averages of monthly $\mathrm{PM}_{1.0}, \mathrm{PM}_{2.5}$, and $\mathrm{PM}_{10.0}$ concentrations in $\mathrm{BD}$ and ULSD buses $\left[\left(\mathrm{PM}_{1.0}: \mathrm{T}=0.48, \mathrm{P}=\right.\right.$ 0.631), $\left(\mathrm{PM}_{2.5}: \mathrm{T}=0.31, \mathrm{P}=0.754\right)$, and $\left(\mathrm{PM}_{10.0}: \mathrm{T}=0.65, \mathrm{P}\right.$ 


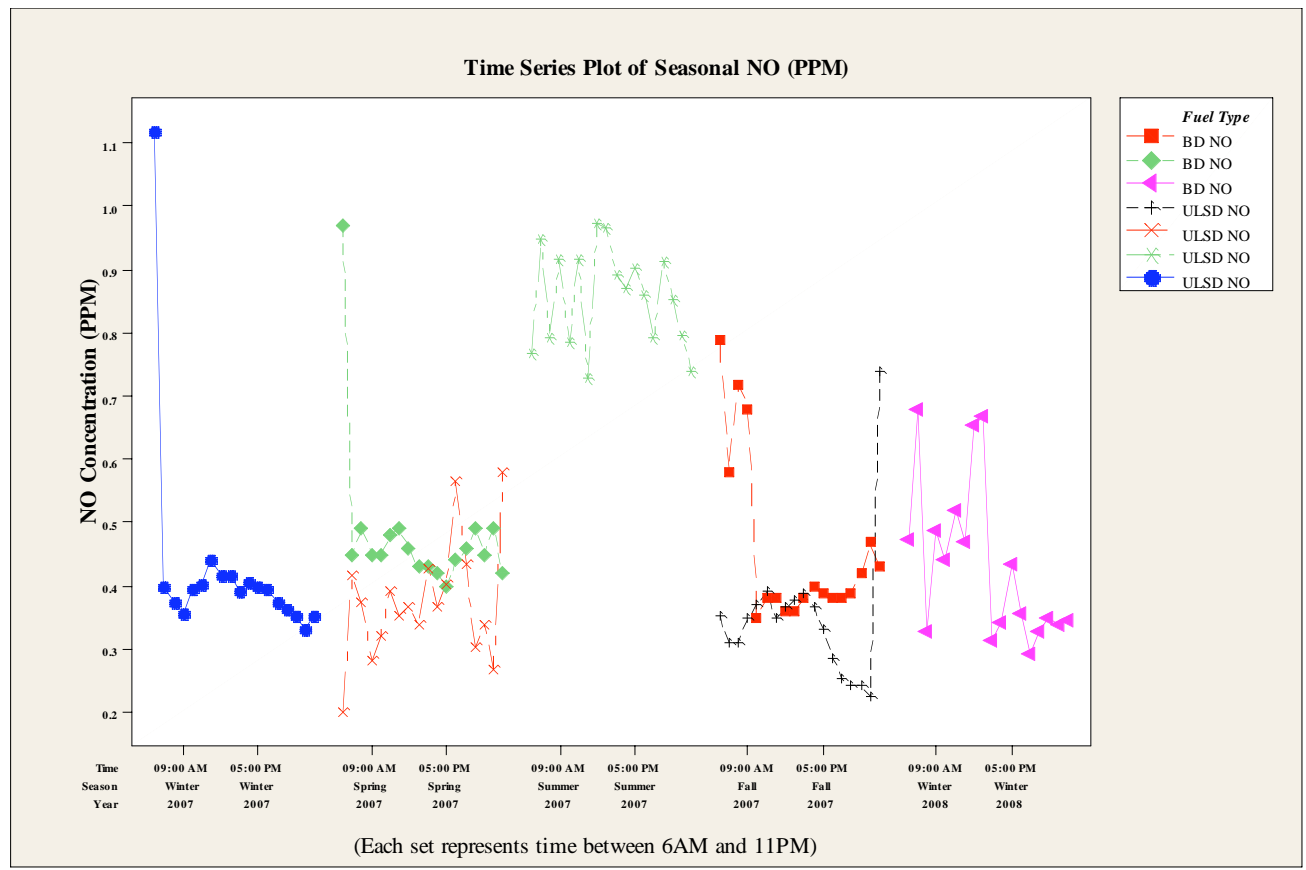

Fig. (9). Seasonal NO concentration trends in BD and ULSD buses.

Table 9. Summary of Statistical Results for Seasonal NO Levels in BD and ULSD Buses

\begin{tabular}{|c|c|c|c|c|c|c|c|c|c|c|c|c|c|c|c|c|}
\hline \multirow{2}{*}{ Season } & \multicolumn{8}{|c|}{ BD (Spring 2007 - Winter 2008) } & & \multicolumn{7}{|c|}{ ULSD (Winter 2007 - Fall 2007) } \\
\hline & $\mathbf{A M}$ & SD & Min. & Max. & Q1 & Q3 & Median & $\mathrm{CV}$ & $\mathbf{A M}$ & SD & Min. & Max. & Q1 & Q3 & Median & CV \\
\hline Winter 2007 & - & - & - & - & - & - & - & - & 0.43 & 0.18 & 0.33 & 1.12 & 0.36 & 0.41 & 0.40 & 0.41 \\
\hline Spring 2007 & 0.48 & 0.13 & 0.39 & 0.97 & 0.43 & 0.48 & 0.45 & 0.27 & 0.37 & 0.09 & 0.20 & 0.58 & 0.32 & 0.42 & 0.37 & 0.25 \\
\hline Summer 2007 & - & - & - & - & - & - & - & - & 0.86 & 0.08 & 0.73 & 0.97 & 0.79 & 0.92 & 0.87 & 0.09 \\
\hline Fall 2007 & 0.46 & 0.14 & 0.35 & 0.79 & 0.38 & 0.47 & 0.39 & 0.30 & 0.35 & 0.11 & 0.22 & 0.74 & 0.29 & 0.37 & 0.35 & 0.32 \\
\hline Winter 2008 & 0.44 & 0.13 & 0.29 & 0.68 & 0.34 & 0.47 & 0.40 & 0.29 & - & - & - & - & - & - & - & - \\
\hline
\end{tabular}

$=0.518)]$. It was observed that monthly $\mathrm{PM}_{1.0}, \mathrm{PM}_{2.5}$, and $\mathrm{PM}_{10.0}$ concentrations in an ultra low sulfur diesel bus $\left[\left(\mathrm{PM}_{1.0} \mu=11.24 \mu \mathrm{g} / \mathrm{m}^{3}, \mathrm{PM}_{2.5} \mu=13.86 \mu \mathrm{g} / \mathrm{m}^{3}\right.\right.$, and $\mathrm{PM}_{10.0}$ $\left.\left.\mu=23.00 \mu \mathrm{g} / \mathrm{m}^{3}\right)\right]$ are statistically similar compared to the monthly $\mathrm{PM}_{1.0}, \mathrm{PM}_{2.5}$, and $\mathrm{PM}_{10.0}$ concentrations observed in a biodiesel bus $\left[\left(\mathrm{PM}_{1.0} \mu=11.87 \mu \mathrm{g} / \mathrm{m}^{3}, \mathrm{PM}_{2.5} \mu=14.32\right.\right.$ $\mu \mathrm{g} / \mathrm{m}^{3}$, and $\left.\left.\mathrm{PM}_{10.0} \mu=24.28 \mu \mathrm{g} / \mathrm{m}^{3}\right)\right]$ for the months during which data were collected simultaneously from both the buses. The biodiesel particulate levels are slightly higher compared to the levels in ultra low sulfur diesel bus. This shows the daily and monthly variations in PM levels are a result of the variation of vehicular traffic with buses and trucks in front of the test vehicle to some extent with ambient particulate concentrations playing a major role.

Table 11 presents the summary of different statistical parameters obtained for $\mathrm{PM}_{1.0}$ concentrations in $\mathrm{BD}$ and ULSD buses on a seasonal basis. Two sample $t$ test indicated that there is statistically no significant difference between mean hourly averages of seasonal $\mathrm{PM}_{1.0}, \mathrm{PM}_{2.5}$, and $\mathrm{PM}_{10.0}$ concentrations in $\mathrm{BD}$ and ULSD buses $\left[\left(\mathrm{PM}_{1.0}: \mathrm{T}=-0.79, \mathrm{P}=\right.\right.$ 0.438), $\left(\mathrm{PM}_{2.5}: \mathrm{T}=-0.90, \mathrm{P}=0.380\right)$, and $\left(\mathrm{PM}_{10.0}: \mathrm{T}=-0.81\right.$,
$\mathrm{P}=0.428)]$. It was observed that seasonal $\mathrm{PM}_{1.0}, \mathrm{PM}_{2.5}$, and $\mathrm{PM}_{10.0}$ concentrations in an ultra low sulfur diesel bus $\left[\left(\mathrm{PM}_{1.0} \mu=11.09 \mu \mathrm{g} / \mathrm{m}^{3}, \mathrm{PM}_{2.5} \mu=13.39 \mu \mathrm{g} / \mathrm{m}^{3}\right.\right.$, and $\mathrm{PM}_{10.0}$ $\left.\left.\mu=20.90 \mu \mathrm{g} / \mathrm{m}^{3}\right)\right]$ are statistically similar compared to the seasonal $\mathrm{PM}_{1.0}, \mathrm{PM}_{2.5}$, and $\mathrm{PM}_{10.0}$ concentrations observed in a biodiesel bus $\left[\left(\mathrm{PM}_{1.0} \mu=9.54 \mu \mathrm{g} / \mathrm{m}^{3}, \mathrm{PM}_{2.5} \mu=11.40\right.\right.$ $\mu \mathrm{g} / \mathrm{m}^{3}$, and $\left.\left.\mathrm{PM}_{10.0} \mu=18.87 \mu \mathrm{g} / \mathrm{m}^{3}\right)\right]$ for the fall 2007 season. The ratios of $\mathrm{PM}_{1.0}$ to $\mathrm{PM}_{2.5}$ and $\mathrm{PM}_{1.0}$ to $\mathrm{PM}_{10.0}$ are observed to be within the ranges of $0.7-0.95$ and $0.5-0.8$ respectively. Seasonal variations of PM levels in ULSD bus were not plotted since the summer 2007 and winter 2008 seasons had only one month of representative samples.

Figs. $(13,14$, and 15) show that the particles with aerodynamic diameter between $0.30 \mu \mathrm{m}$ and $0.40 \mu \mathrm{m}$ constitute the majority of the composition for $\mathrm{PM}_{1.0}$. Table 12 presents the summary of different statistical parameters obtained for particle numbers with diameter between $0.30 \mu \mathrm{m}$ and 0.40 $\mu \mathrm{m}$ concentrations in BD and ULSD buses on a monthly basis. Two sample $t$ test indicated that there is statistically significant difference between mean hourly averages of particle numbers with diameter between $0.30 \mu \mathrm{m}$ and $0.40 \mu \mathrm{m}$ 


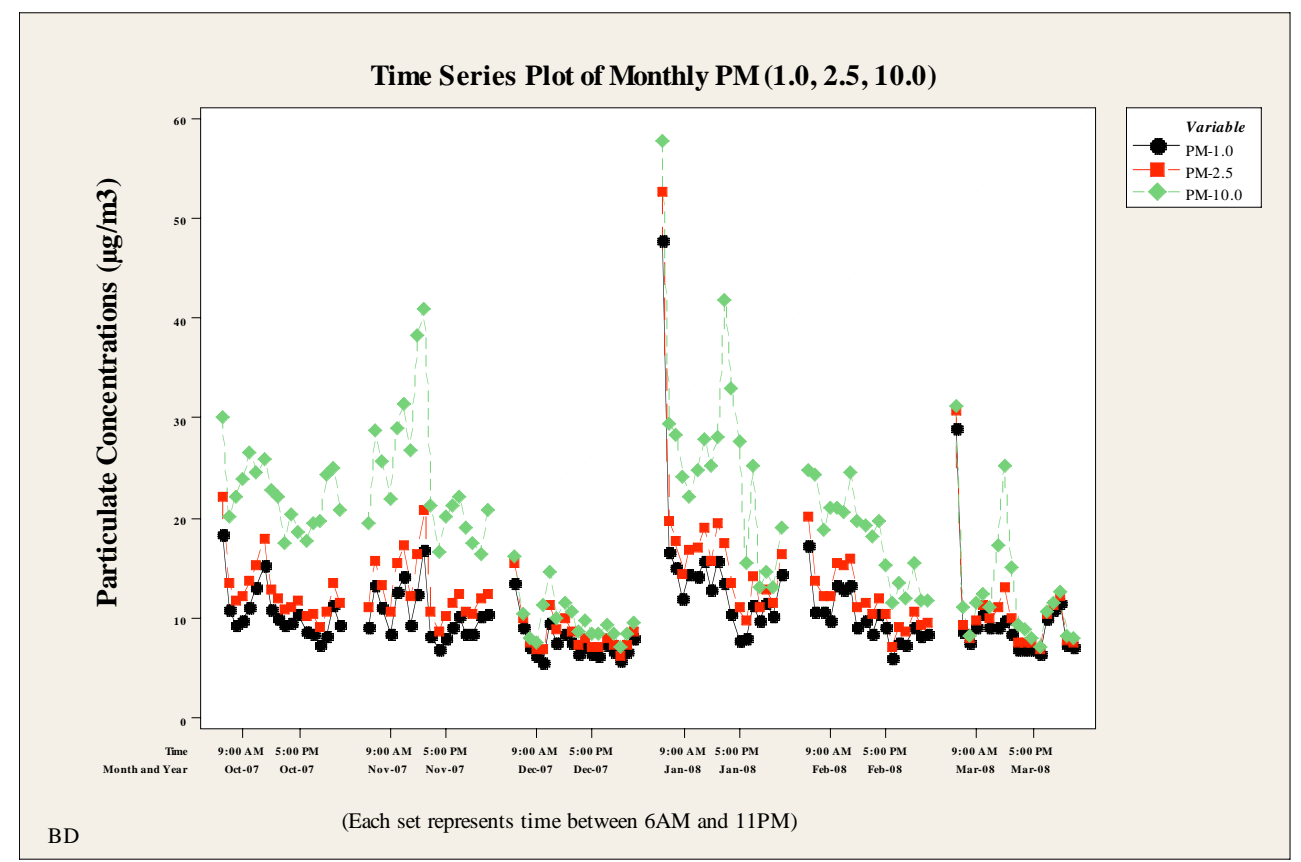

Fig. (10). Monthly PM $(1.0,2.5,10.0)$ concentration trends in a BD bus.

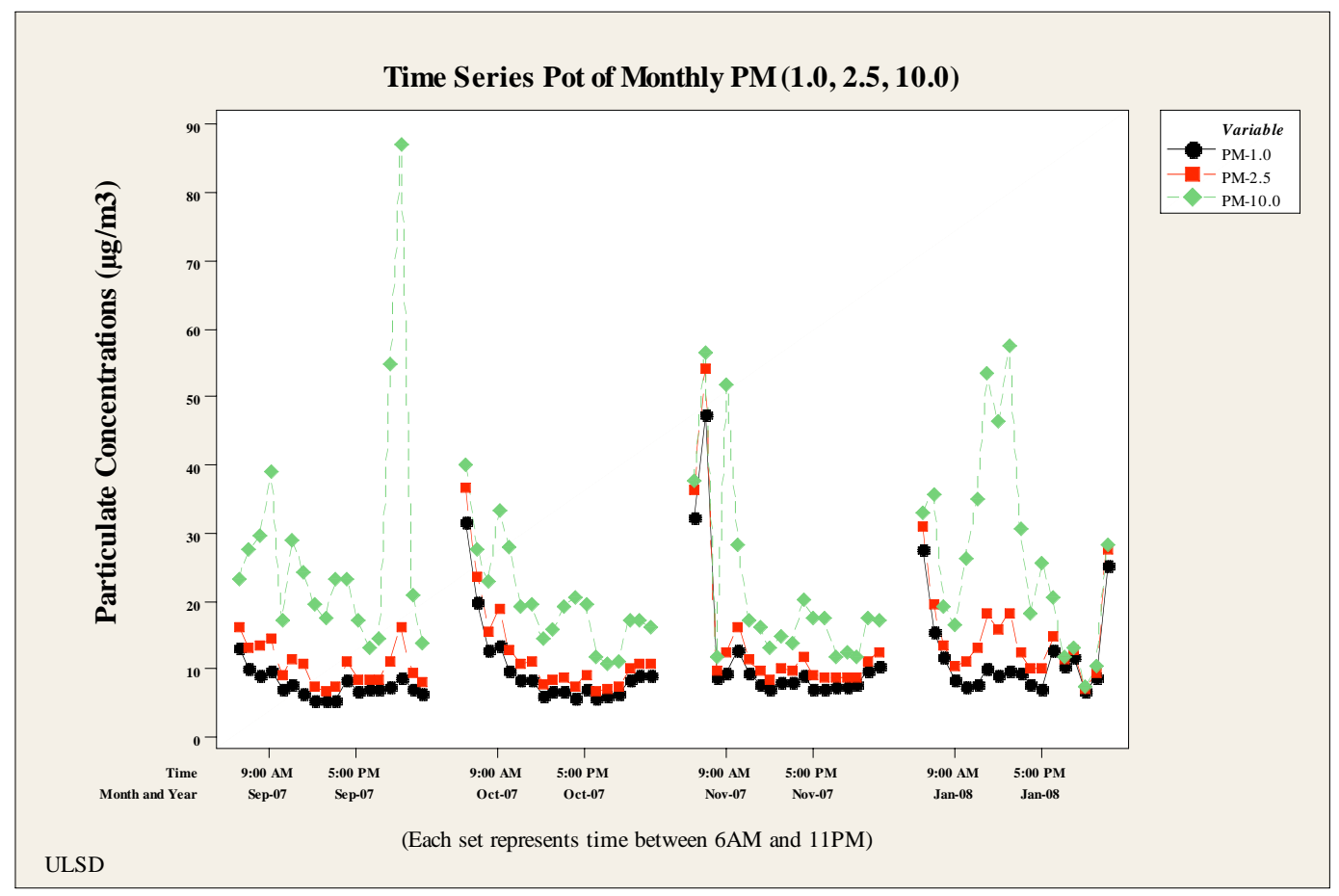

Fig. (11). Monthly PM $(1.0,2.5,10.0)$ concentration trends in ULSD bus.

Table 10. Summary of Statistical Results for Monthly $\mathbf{P M}_{1.0}$ Levels in BD and ULSD Buses

\begin{tabular}{|c|c|c|c|c|c|c|c|c|c|c|c|c|c|c|c|c|}
\hline Month & \multicolumn{8}{|c|}{ BD (Oct. 2007 - Mar. 2008) } & \multicolumn{8}{|c|}{ ULSD (Sep. 2007 - Jan. 2007) } \\
\hline Oct. 2007 & 10.64 & 2.66 & 7.45 & 18.30 & 9.26 & 11.15 & 9.91 & 0.25 & 10.08 & 6.46 & 5.61 & 31.74 & 6.45 & 9.71 & 8.35 & 0.64 \\
\hline
\end{tabular}


Table 10. contd...

\begin{tabular}{|c|c|c|c|c|c|c|c|c|c|c|c|c|c|c|c|c|}
\hline \multirow{2}{*}{ Month } & \multicolumn{8}{|c|}{ BD (Oct. 2007 - Mar. 2008) } & \multicolumn{8}{|c|}{ ULSD (Sep. 2007 - Jan. 2007) } \\
\hline & $\mathbf{A M}$ & SD & Min. & Max. & Q1 & Q3 & Median & $\mathrm{CV}$ & $\mathbf{A M}$ & SD & Min. & Max. & Q1 & Q3 & Median & $\mathbf{C V}$ \\
\hline Nov. 2007 & 10.44 & 2.60 & 6.87 & 16.94 & 8.46 & 12.37 & 9.77 & 0.25 & 12.10 & 10.57 & 6.94 & 47.56 & 7.57 & 9.69 & 8.53 & 0.87 \\
\hline Dec. 2007 & 7.55 & 1.87 & 5.48 & 13.64 & 6.43 & 7.97 & 7.10 & 0.25 & - & - & - & - & - & - & - & - \\
\hline Jan. 2008 & 14.54 & 8.70 & 7.88 & 47.80 & 10.48 & 15.04 & 13.24 & 0.60 & 11.53 & 5.90 & 6.70 & 27.75 & 7.70 & 11.71 & 9.72 & 0.51 \\
\hline Feb. 2008 & 10.09 & 2.69 & 5.94 & 17.22 & 8.37 & 10.77 & 9.52 & 0.27 & - & - & - & - & - & - & - & - \\
\hline Mar. 2008 & 9.77 & 5.03 & 6.56 & 28.97 & 7.08 & 9.84 & 8.89 & 0.51 & - & - & - & - & - & - & - & - \\
\hline
\end{tabular}

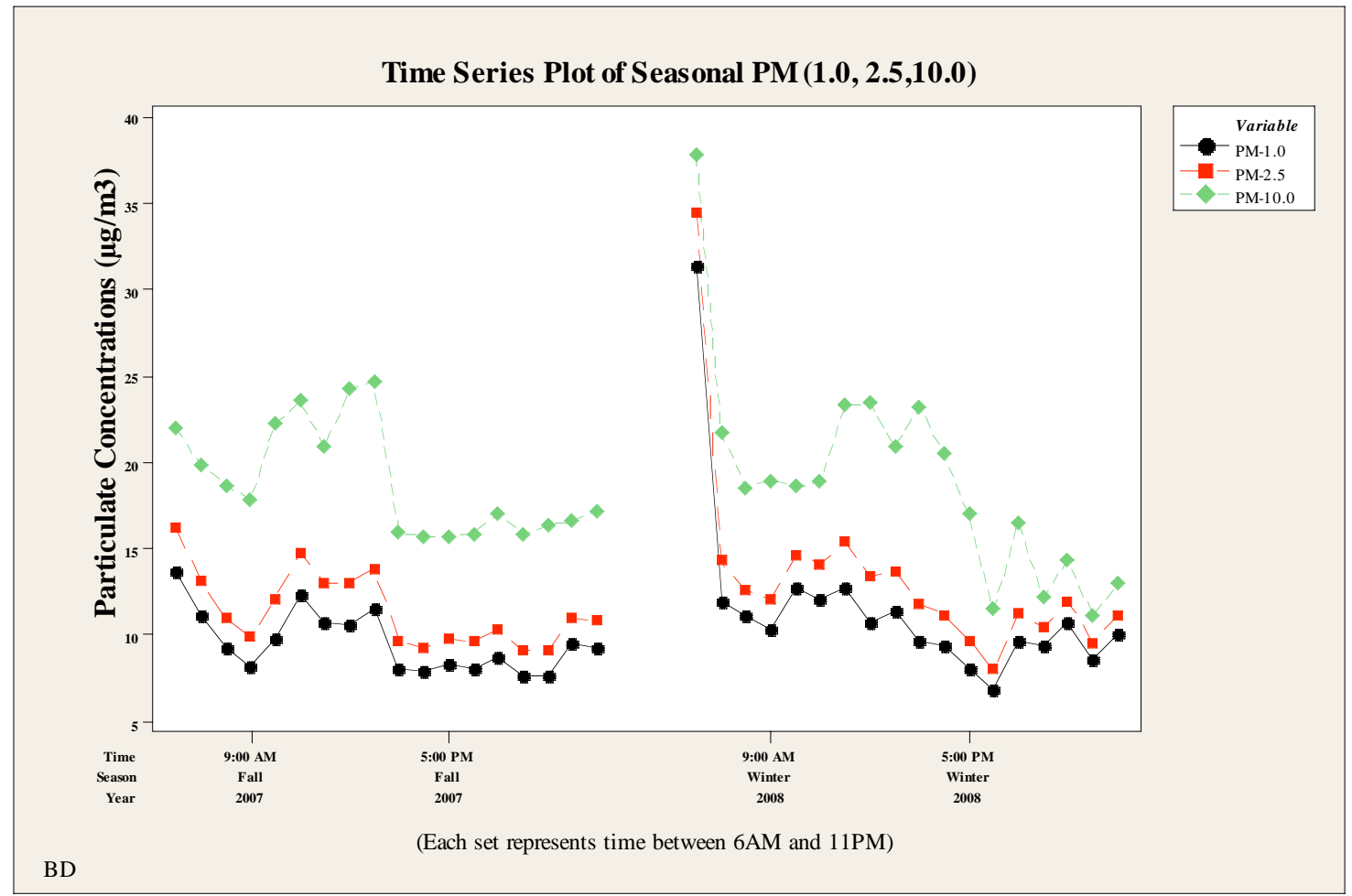

Fig. (12). Seasonal PM $(1.0,2.5,10.0)$ concentration trends in a BD bus.

Table 11. Summary of Statistical Results for Seasonal $P_{1.0}$ Levels in BD and ULSD Buses

\begin{tabular}{|c|c|c|c|c|c|c|c|c|c|c|c|c|c|c|c|c|}
\hline \multirow{2}{*}{ Season } & \multicolumn{8}{|c|}{ BD (Fall 2007 - Winter 2008) } & & \multicolumn{7}{|c|}{ ULSD (Fall 2007) } \\
\hline & $\mathbf{A M}$ & SD & Min. & Max. & Q1 & Q3 & Median & CV & $\mathbf{A M}$ & SD & Min. & Max. & Q1 & Q3 & Median & CV \\
\hline Winter 2008 & 11.47 & 5.20 & 6.82 & 31.33 & 9.38 & 11.92 & 10.50 & 0.45 & - & - & - & - & - & - & - & - \\
\hline
\end{tabular}

$(\mathrm{T}=3.84, \mathrm{P}=0.000)$. It was observed that monthly particle numbers having size range between $0.30 \mu \mathrm{m}$ and $0.40 \mu \mathrm{m}$ in an ultra low sulfur diesel bus $(\mu=49813$ particles/litre $)$ are statistically significantly lower compared to the particle numbers with diameter between $0.30 \mu \mathrm{m}$ and $0.40 \mu \mathrm{m}$ observed in the biodiesel bus $(\mu=82609$ particles/litre) for the months from January 2007 to March 2007.
Table 13 presents the summary of different statistical parameters obtained for particle numbers with diameter between $0.30 \mu \mathrm{m}$ and $0.40 \mu \mathrm{m}$ concentrations in BD and ULSD buses on a seasonal basis. Two sample $t$ test indicated that there is statistically significant difference between mean hourly averages of particle numbers with diameter between $0.30 \mu \mathrm{m}$ and $0.40 \mu \mathrm{m}(\mathrm{T}=3.48, \mathrm{P}=0.003)$ for winter 2007 . 


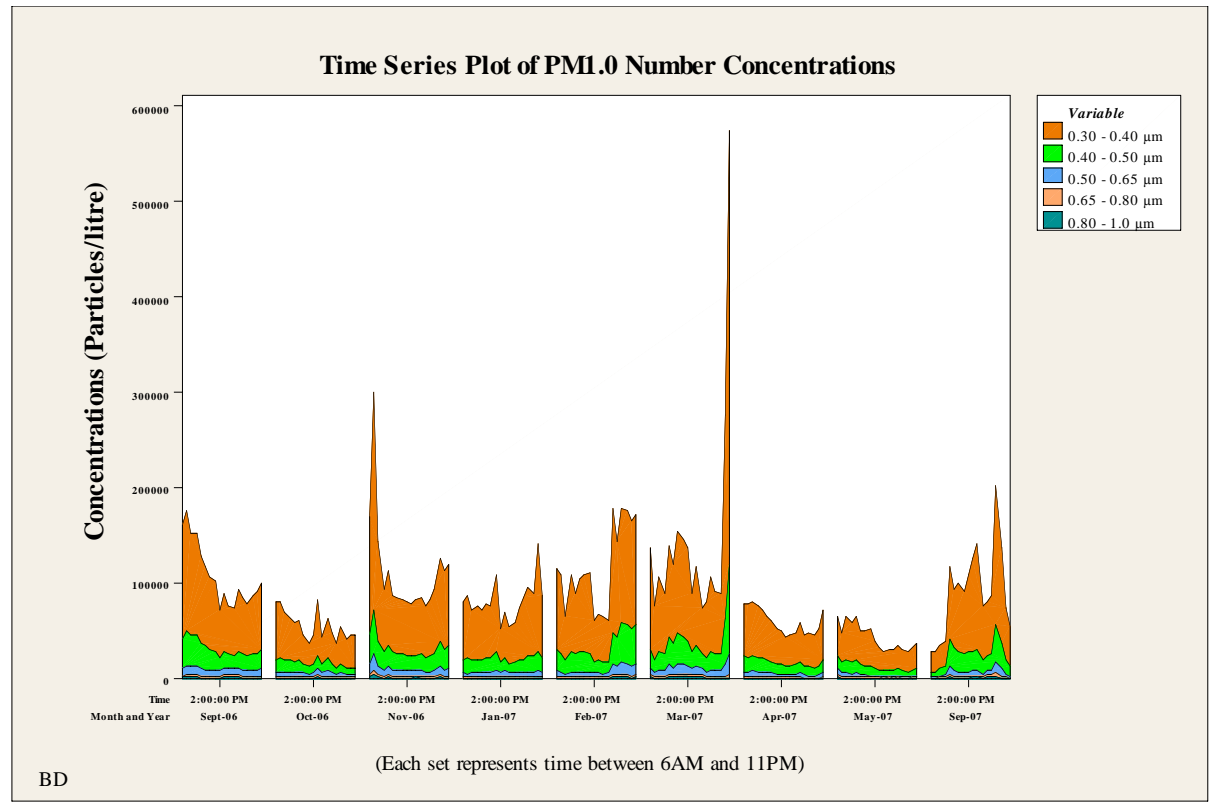

Fig. (13). Avg. monthly variation of $\mathrm{PM}_{1.0}$ components (Particle Counts) in a BD bus.

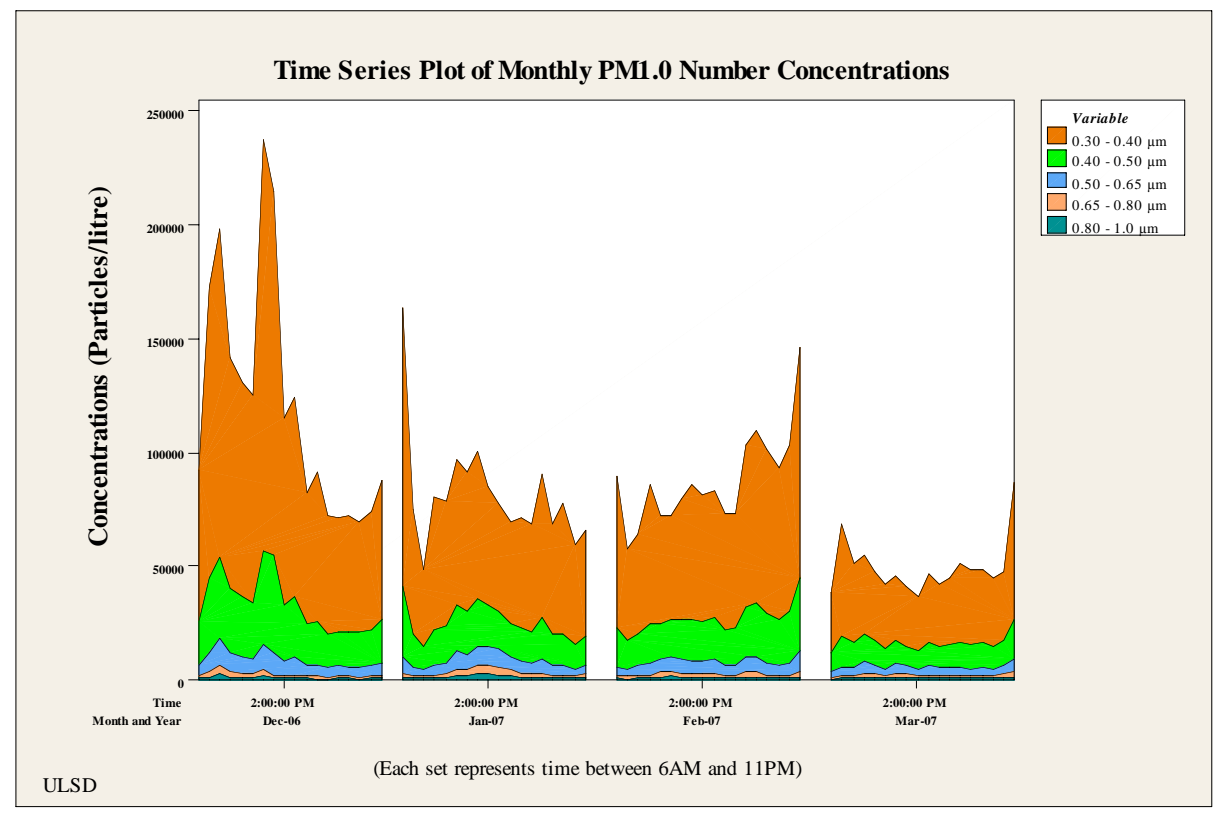

Fig. (14). Avg. monthly variation of $\mathrm{PM}_{1.0}$ components (Particle Counts) in ULSD bus.

It was observed that seasonal particle numbers having size range between $0.30 \mu \mathrm{m}$ and $0.40 \mu \mathrm{m}$ in a biodiesel bus $(\mu=$ 82609 particles/litre) are statistically significantly higher compared to the particle numbers with diameter between $0.30 \mu \mathrm{m}$ and $0.40 \mu \mathrm{m}$ observed in an ultra low sulfur diesel bus ( $\mu=49813$ particles/litre) for winter 2007 . The particulate matter levels were influenced by vehicular traffic, ventilation settings, and the speed of vehicle in addition to ambient PM levels.

\section{CONCLUSIONS}

A field study to continuously collect indoor air quality data in two public transport buses running on biodiesel and ultra low sulfur diesel for a period of one year was success- fully completed. A comprehensive study of the in-vehicle pollutant trends helped in a better understanding of the indoor air quality in a bus. Trends of pollutant concentrations were studied to identify the daily, monthly, and seasonal patterns. The trend and statistical analyses revealed:

$>$ Repetitive trends are observed for each pollutant exclusive of PM with respect to time of day.

$>$ All the pollutant concentrations increased during the peak hours.

$>$ Indoor pollutant levels are generally found to be higher in winter months as compared to summer months, due to lower air exchange from outside the vehicle into the bus compartment. 
Table 12. Summary of Statistical Results for Monthly $\mathbf{P M}_{1.0}$ Number Concentrations in BD and ULSD Buses (Diameter Range: $0.30 \mu \mathrm{m}-0.40 \mu \mathrm{m})$

\begin{tabular}{|c|c|c|c|c|c|c|c|c|c|c|c|c|c|c|c|c|}
\hline \multirow[b]{2}{*}{ Month } & \multicolumn{8}{|c|}{ BD (Sep. 2006 - Sep. 2007) } & \multicolumn{8}{|c|}{ ULSD (Dec. 2006 - Mar. 2007) } \\
\hline & $\mathbf{A M}$ & SD & Min. & Max. & Q1 & Q3 & $\begin{array}{l}\text { Me- } \\
\text { dian }\end{array}$ & CV & $\mathbf{A M}$ & SD & Min. & Max. & Q1 & Q3 & $\begin{array}{l}\text { Me- } \\
\text { dian }\end{array}$ & $\begin{array}{l}\text { C } \\
\text { V }\end{array}$ \\
\hline $\begin{array}{l}\text { Sep. } \\
2006\end{array}$ & $\begin{array}{l}7631 \\
1.08\end{array}$ & $\begin{array}{c}24385 \\
.45\end{array}$ & $\begin{array}{c}49427 \\
.10\end{array}$ & $\begin{array}{c}12795 \\
7.11\end{array}$ & $\begin{array}{c}59040 \\
.81\end{array}$ & $\begin{array}{c}90295 . \\
56\end{array}$ & $\begin{array}{c}67886 \\
.01\end{array}$ & 0.32 & - & - & - & - & - & - & - & - \\
\hline $\begin{array}{l}\text { Oct. } \\
2006\end{array}$ & $\begin{array}{l}3915 \\
5.58\end{array}$ & $\begin{array}{c}11417 \\
.94\end{array}$ & $\begin{array}{c}25882 \\
.63\end{array}$ & $\begin{array}{c}61096 . \\
48\end{array}$ & $\begin{array}{c}30672 \\
.14\end{array}$ & $\begin{array}{c}43605 . \\
52\end{array}$ & $\begin{array}{c}36292 \\
.70\end{array}$ & 0.29 & - & - & - & - & - & - & - & - \\
\hline $\begin{array}{l}\text { Nov. } \\
2006\end{array}$ & $\begin{array}{l}7976 \\
8.34\end{array}$ & $\begin{array}{c}41991 \\
.35\end{array}$ & $\begin{array}{c}53907 \\
.00\end{array}$ & $\begin{array}{c}22895 \\
4.11\end{array}$ & $\begin{array}{c}57886 \\
.04\end{array}$ & $\begin{array}{c}85363 . \\
12\end{array}$ & $\begin{array}{c}62135 \\
.03\end{array}$ & 0.53 & - & - & - & - & - & - & - & - \\
\hline $\begin{array}{l}\text { Dec. } \\
2006\end{array}$ & - & - & - & - & - & - & - & - & $\begin{array}{l}8741 \\
4.26\end{array}$ & $\begin{array}{c}40815 \\
.79\end{array}$ & $\begin{array}{c}48074 \\
.57\end{array}$ & $\begin{array}{c}18031 \\
6.05\end{array}$ & $\begin{array}{c}51988 \\
.98\end{array}$ & $\begin{array}{c}10125 \\
3.95\end{array}$ & $\begin{array}{c}74566 \\
.93\end{array}$ & $\begin{array}{l}0 . \\
47\end{array}$ \\
\hline $\begin{array}{c}\text { Jan. } \\
2007\end{array}$ & $\begin{array}{l}5965 \\
0.39\end{array}$ & $\begin{array}{c}17489 \\
.05\end{array}$ & $\begin{array}{c}34807 \\
.15\end{array}$ & $\begin{array}{c}11193 \\
2.15\end{array}$ & $\begin{array}{c}51485 \\
.12\end{array}$ & $\begin{array}{c}66539 . \\
50\end{array}$ & $\begin{array}{c}55929 \\
.65\end{array}$ & 0.29 & $\begin{array}{c}5626 \\
1.59\end{array}$ & $\begin{array}{c}18427 \\
.50\end{array}$ & $\begin{array}{c}33681 \\
.99\end{array}$ & $\begin{array}{c}12217 \\
2.42\end{array}$ & $\begin{array}{c}46734 \\
.64\end{array}$ & $\begin{array}{c}60772 . \\
41\end{array}$ & $\begin{array}{c}53603 \\
.76\end{array}$ & $\begin{array}{c}0 . \\
33\end{array}$ \\
\hline $\begin{array}{l}\text { Feb. } \\
2007\end{array}$ & $\begin{array}{l}8213 \\
1.24\end{array}$ & $\begin{array}{c}29229 \\
.32\end{array}$ & $\begin{array}{c}42747 \\
.09\end{array}$ & $\begin{array}{c}13004 \\
2.99\end{array}$ & $\begin{array}{c}47796 \\
.66\end{array}$ & $\begin{array}{c}11298 \\
7.68\end{array}$ & $\begin{array}{c}82141 \\
.98\end{array}$ & 0.36 & $\begin{array}{l}6052 \\
6.64\end{array}$ & $\begin{array}{c}14924 \\
.30\end{array}$ & $\begin{array}{c}40311 \\
.04\end{array}$ & $\begin{array}{c}10148 \\
7.94\end{array}$ & $\begin{array}{c}50394 \\
.52\end{array}$ & $\begin{array}{c}71469 . \\
87\end{array}$ & $\begin{array}{c}57710 \\
.40\end{array}$ & $\begin{array}{c}0 . \\
25\end{array}$ \\
\hline $\begin{array}{l}\text { Mar. } \\
2007\end{array}$ & $\begin{array}{r}1060 \\
45.56\end{array}$ & $\begin{array}{c}94208 \\
.91\end{array}$ & $\begin{array}{c}48427 \\
.97\end{array}$ & $\begin{array}{c}45420 \\
7.74\end{array}$ & $\begin{array}{c}62916 \\
.93\end{array}$ & $\begin{array}{c}10231 \\
0.37\end{array}$ & $\begin{array}{c}79205 \\
.07\end{array}$ & 0.89 & $\begin{array}{r}3265 \\
1.44\end{array}$ & $\begin{array}{c}8764 . \\
21\end{array}$ & $\begin{array}{c}24137 \\
.29\end{array}$ & $\begin{array}{c}60006 . \\
35\end{array}$ & $\begin{array}{c}27680 \\
.01\end{array}$ & $\begin{array}{c}33248 \\
19\end{array}$ & $\begin{array}{c}30370 \\
.60\end{array}$ & $\begin{array}{l}0 . \\
27\end{array}$ \\
\hline $\begin{array}{l}\text { Apr. } \\
2007\end{array}$ & $\begin{array}{l}4264 \\
7.17\end{array}$ & $\begin{array}{c}9097 . \\
72\end{array}$ & $\begin{array}{c}30559 \\
.50\end{array}$ & $\begin{array}{c}56017 . \\
60\end{array}$ & $\begin{array}{c}34589 \\
.53\end{array}$ & $\begin{array}{c}52583 . \\
82\end{array}$ & $\begin{array}{c}40189 \\
.96\end{array}$ & 0.21 & - & - & - & - & - & - & - & - \\
\hline $\begin{array}{l}\text { May. } \\
2007\end{array}$ & $\begin{array}{l}3058 \\
2.94\end{array}$ & $\begin{array}{c}8971 . \\
83\end{array}$ & $\begin{array}{c}20222 \\
.46\end{array}$ & $\begin{array}{c}46040 . \\
90\end{array}$ & $\begin{array}{c}23400 \\
.58\end{array}$ & $\begin{array}{c}38935 . \\
67\end{array}$ & $\begin{array}{c}27494 \\
.91\end{array}$ & 0.29 & - & - & - & - & - & - & - & - \\
\hline $\begin{array}{l}\text { Sep. } \\
2007\end{array}$ & $\begin{array}{l}6519 \\
0.32\end{array}$ & $\begin{array}{c}33372 \\
.99\end{array}$ & $\begin{array}{c}21002 \\
.89\end{array}$ & $\begin{array}{c}14565 \\
4.01\end{array}$ & $\begin{array}{c}41282 \\
.29\end{array}$ & $\begin{array}{c}76720 . \\
71\end{array}$ & $\begin{array}{c}61653 \\
.52\end{array}$ & 0.51 & - & - & - & - & - & - & - & - \\
\hline
\end{tabular}

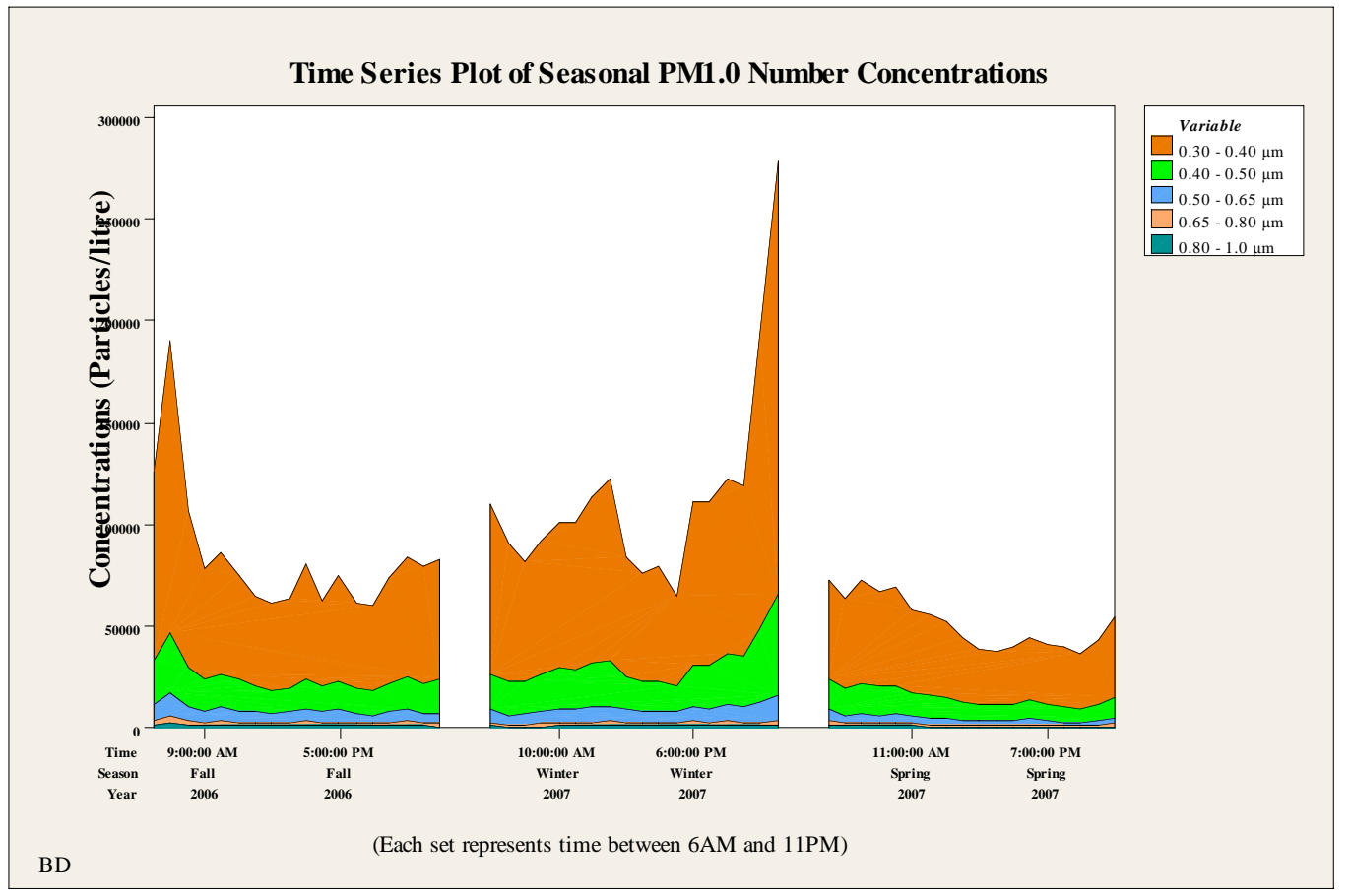

Fig. (15). Avg. seasonal variation of $\mathrm{PM}_{1.0}$ components (Particle Counts) in a BD bus. 
Table 13. Summary of Statistical Results for Seasonal $P M_{1.0}$ Number Concentrations in BD and ULSD Buses (Diameter Range: $0.30 \mu \mathrm{m}-0.40 \mu \mathrm{m})$

\begin{tabular}{|c|c|c|c|c|c|c|c|c|c|c|c|c|c|c|c|c|}
\hline \multirow{2}{*}{ Season } & \multicolumn{8}{|c|}{ BD (Fall 2006 - Spring 2007) } & \multicolumn{8}{|c|}{ ULSD (Winter 2007) } \\
\hline & $\mathbf{A M}$ & SD & Min. & Max. & Q1 & Q3 & Median & CV & $\mathbf{A M}$ & SD & Min. & Max. & Q1 & Q3 & Median & CV \\
\hline $\begin{array}{c}\text { Fall } \\
2006\end{array}$ & 59461.96 & 24737.38 & 41920.07 & 143755.98 & 43354.85 & 59567.79 & 53159.90 & 0.42 & - & - & - & - & - & - & - & - \\
\hline $\begin{array}{c}\text { Winter } \\
2007\end{array}$ & 82609.06 & 38940.29 & 43862.78 & 211987.46 & 58569.43 & 83962.62 & 76006.15 & 0.47 & 49813.22 & 8863.92 & 37275.27 & 71759.34 & 44208.02 & 51039.93 & 48662.65 & 0.18 \\
\hline $\begin{array}{c}\text { Spring } \\
2007\end{array}$ & 36615.06 & 8376.44 & 26242.85 & 50289.26 & 29726.70 & 40448.65 & 35000.75 & 0.23 & - & - & - & - & - & - & - & - \\
\hline
\end{tabular}

$>$ Peak concentrations are observed at traffic signals when the bus is in an idling position along with other vehicles.

$>$ While the daily variation of carbon dioxide is due to a combination of passenger ridership, vehicular traffic, ventilation settings and bus status, monthly and seasonal variations are caused mainly by vehicular traffic and ventilation settings.

$>$ The daily, monthly, and seasonal variations of carbon monoxide and sulfur dioxide are mainly caused by the combination of vehicular traffic, ventilation settings and, to an extent, by vehicle speed.

$>$ The daily and monthly variations of NO are mainly a result of varying traffic and ventilation settings while seasonal variation is a result of change in ventilation settings.

$>$ The daily and monthly variation in the particulate matter levels is a result of change in ambient particulate concentrations and varying vehicular traffic with buses and trucks in front of the test vehicle playing a major role while seasonal variation is caused by a combination of vehicular traffic, ventilation settings, and speed of vehicle in addition to ambient PM concentrations.

$>$ The pollutant levels of $\mathrm{CO}_{2}$ and $\mathrm{SO}_{2}$ are found to be statistically significantly higher in an ultra low sulfur diesel bus while the pollutant levels of $\mathrm{CO}, \mathrm{NO}$, particle numbers with size range between $0.30 \mu \mathrm{m}$ and $0.40 \mu \mathrm{m}$ are found to be statistically significantly higher in a biodiesel bus. PM concentrations are found to be statistically similar for both the test buses.

\section{ACKNOWLEDGEMENTS}

The authors would like to thank the United States Department of Transportation (USDOT) and the Toledo Area Regional Transit Authority (TARTA) for the alternative fuel grant awarded to the Intermodal Transportation Institute (ITI) of The University of Toledo. The authors would also like to express their sincere gratitude to the TARTA management and the employees for their continued interest and involvement in this work. The views expressed in this paper are those of the authors alone and do not represent the views of the funding organizations.

\section{REFERENCES}

[1] Klepeis NE, Nelson WC, Ott WR, et al. The national human activity pattern survey (NHAPS): a resource for assessing exposure to environmental pollutants. J Exposure Anal Environ Epidemiol 2001; 11: 231-52.

[2] U.S Environmental Protection Agency, National Emissions Inventory Booklet, 2002 [Cited 2008 Apr 15]. Available from http://www.epa.gov/ttn/chief/net/2002neibooklet.pdf.

[3] California Office of Environmental Health Hazard Assessment, Air pollution from nearby traffic and children's health: Information for schools, 2004 [Cited 2008 July 15]. Available from http://oehha.ca.gov/public_info/facts/pdf/Factsheetschools.pdf.

[4] California Air Resources Board, Children's school bus exposure study, 2003 [Cited 2008 July 15]. Available from http://www.arb.ca.gov/research/schoolbus/sbfact.pdf.

[5] Fitz DR, Winer AM, Colome S, et al. Characterizing the range of children's pollutant exposure during school bus commutes. Final report. Contract No. 00-322. California Air Resources Board, Research Division, Sacramento, CA 2003.

[6] Rodes C, Sheldon L, Whitaker D, et al. Measuring concentrations of selected air pollutants inside california vehicles. Final Report. Contract No. 95-339. California Air Resources Board, Research Division, Sacramento, CA 1998.

[7] Fruin SA. Black carbon concentrations inside vehicles: Implications for refined diesel particulate matter exposures. Ph.D. Dissertation, University of California, Los Angeles 2003.

[8] Praml G, Schierl R. Dust exposure in Munich public transportation: a comprehensive 4-year survey in buses and trams. Int Arch Occup Environ Health 2000; 73: 209-14.

[9] Adams HS, Nieuwenhuijsen MJ, Colvile RN. Determinants of fine particle $\left(\mathrm{PM}_{2.5}\right)$ personal exposure levels in transport microenvironments, London, UK. Atmos Environ 2001; 35: 4557-66.

[10] Sabin L, Kozawa K, Behrentz E, et al. Analysis of real-time variables affecting children's exposure to diesel-related pollutants during school bus commutes in Los Angeles. Atmos Environ 2005; 39: 5243-54.

[11] Vijayan A, Kumar A. Characterization of indoor air quality inside public transport buses using alternative diesel fuels. Paper \#082937 In Proceedings of TRB Conference, Transportation Research Board, Washington, D.C. 2008; p. 17.

[12] Zhang GS, Li TT, Luo M, et al. Air pollution in the microenvironment of parked new cars. Build Environ 2008; 43: 315-19.

[13] Fedoruk MJ, Kerger BD. Measurement of volatile organic compounds inside automobiles. J Exp Anal Environ Epidemiol 2003; 13: 31-41.

[14] Chan CC, Ozkaynak H, Spengler JD, Sheldon L. Driver exposure to volatile organic compounds, carbon monoxide, ozone, and nitrogen dioxide under different driving conditions. Environ Sci Technol 1991; 25: 964-72.

[15] Diapouli E, Grivas G, Chaloulakou A, Spyrellis N. $\mathrm{PM}_{10}$ and ultrafine particles counts in-vehicle and on-road in the Athens Area. Water Air Soil Pollut Focus 2008; 8: 89-97.

[16] Chan LY, Lau WL, Wang XM, Tang JH. Preliminary measurements of aromatic VOCs in public transportation modes in Guangzhou, China. Environ Int 2003; 29: 429-35.

[17] Chan LY, Lau WL, Zou SC, Cao ZX, Lai SC. Exposure level of carbon monoxide and respirable suspended particulate in public transportation modes while commuting in urban area of Guangzhou, China. Atmos Environ 2002; 36: 5831-40. 
[18] Chan LY, Liu YM. Carbon monoxide levels in popular passenger commuting modes traversing major commuting routes in Hong Kong. Atmos Environ 2001; 35: 2637-46.

[19] Duffy BL, Nelson PF. Exposure to emissions of 1,3-butadiene and benzene in the cabins of moving motor vehicles and buses in Sydney, Australia. Atmos Environ 1997; 31: 3877-85.

[20] Gulliver J, Briggs DJ. Personal exposure to particulate air pollution in transport microenvironments. Atmos Environ 2004; 38: 1-8.

[21] Gomez-Perales JE, Colvile RN, Nieuwenhuijsen MJ, et al. Commuters' exposure to $\mathrm{PM}_{2.5}, \mathrm{CO}$, and benzene in public transport in the metropolitan area of Mexico City. Atmos Environ 2004; 38: 1219-29.

[22] Fernandez-Bremauntz AA, Ashmore M. Exposure of commuters to carbon monoxide in Mexico City - 1. Measurement of in-vehicle concentrations. Atmos Environ 1995; 29: 525-32.

[23] Clifford MJ, Clarke R, Riffat SB. Driver's exposure to carbon monoxide in Nottingham, UK. Atmos Environ 1997; 31: 1003-9.

[24] Chan LY, Lau WL, Lee SC, Chan CY. Commuter exposure to particulate matter in public transportation modes in Hong Kong. Atmos Environ 2002; 36: 3363-73.

[25] Lau WL, Chan LY. Commuter exposure to aromatic VOCs in public transportation modes in Hong Kong. Sci Total Environ 2003; 308: 143-55.

[26] Chan LY, Chan CY, Qin Y. The effect of commuting microenvironment on commuter exposures to vehicular emission in Hong Kong. Atmos Environ 1999; 33: 1777-87.

[27] Kuo HW, Wei HC, Liu CS, et al. Exposure to volatile organic compounds while commuting in Taichung, Taiwan. Atmos Environ 2000; 34: 3331-6.

[28] Chan A. Commuter exposure and indoor-outdoor relationships of carbon oxides in buses in Hong Kong. Atmos Environ 2003; 37: 3809-15.

[29] Alm S, Jantunen MJ, Vartiainen M. Urban commuter exposure to particulate matter and carbon monoxide inside an automobile. J Exposure Anal Environ Epidemiol 1999; 9: 237-44

[30] Adams HS, Nieuwenhuijsen MJ, Colvile RN, McMullen MA, Khandelwal P. Fine particle $\left(\mathrm{PM}_{2.5}\right)$ personal exposure levels in transport microenvironments, London, UK. Sci Total Environ 2001; 279: 29-44.

[31] Hammond DM, Lalor MM, Jones SL. In-vehicle measurement of particle number concentrations on school buses equipped with diesel retrofits. Water Air Soil Pollut 2007; 179: 217-25.

[32] Duci A, Chaloulakou A, Spyrellis N. Exposure to carbon monoxide in the Athens urban area during commuting. Sci Total Environ 2003; 309: 47-58.

[33] Kadiyala A, Kumar A, Vijayan A. Study of occupant exposure of drivers and commuters with temporal variation of in-vehicle pollutant concentrations in public transport buses operating on alternative diesel fuels. Open Environ Eng 2010; 3: 55-70.
[34] Lawryk NJ, Lioy PJ, Weisel CP. Exposure to volatile organic compounds in the passenger compartment of automobiles during periods of normal and malfunctioning operation. J Exp Anal Environ Epidemiol 1995; 5: 511-31.

[35] Ptak TJ, Fallon SL. Particulate concentration in automobile passenger compartments. Part Sci Technol 1994; 12: 313-22.

[36] Solomon GM, Campbell TR, Feuer GR, Masters J, Samkian A, Paul KA. No breathing in the aisles: Diesel exhaust inside school buses. Natural Resources Defense Council and Coalition for Clean Air, New York 2001

[37] van Wijnen JH, van der Zee SC. Traffic-related air pollutants: exposure of road users and populations living near busy roads. Rev Environ Health 1998; 13: 1-25.

[38] Flachsbart PG. Human exposure to carbon monoxide from mobile sources. Chemosp Glob Change Sci 1999; 1: 301-29.

[39] Kaur S, Nieuwenhuijsen MJ, Colvile RN. Fine particulate matter and carbon monoxide exposure concentrations in urban street transport microenvironments. Atmos Environ 2007; 41: 4781-810.

[40] Kadiyala A, Kumar A. Application of CART and Minitab software to identify variables affecting indoor concentration levels, Environ Prog 2008; 27: 160-8.

[41] Kadiyala, A.; Kumar, A. Study of in-vehicle pollutant behavior in public transport buses running on alternative fuels. Paper \#571 In Proceedings of the 2009 A\&WMA Annual Conference Detroit 2009.

[42] Kadiyala A. Identification of factors affecting contaminant levels and determination of infiltration of ambient contaminants in public transport buses operating on biodiesel and ULSD fuels. Master's Thesis, University of Toledo, Toledo 2008.

[43] Vijayan A, Kumar A, Abraham M. Characterization of sub-1.0 $\mu \mathrm{m}$ particulate matter distribution inside public transport buses. Paper \#528 In Proceedings of the 2007 A\&WMA Annual Conference Pittsburgh 2007.

[44] GRIMM Technologies, Inc. [Cited 2008 Apr 15]. Available from http://www.dustmonitor.com/.

[45] TSI Inc. [Cited 2008 Apr 15]. Available from http://www.tsi.com/ en-1033/index.aspx.

[46] Critical Environmental Technologies. [Cited 2008 Apr 15]. Available from http://www.critical-environment.com/.

[47] TARTA Route \#20 [Cited 2008 Apr 15], Available from http://www.tarta.com/wp-content/uploads/routes/20.pdf.

[48] National Climatic Data Center (NCDC NOAA) [Cited 2008 Apr 15], Available from http://cdo.ncdc.noaa.gov/ulcd/ULCD.

[49] Vijayan A. Characterization of vehicular exhaust emissions and indoor air quality of public transport buses operating on alternative diesel fuels. Ph.D. Dissertation, University of Toledo, Toledo 2007.

[50] Vijayan A, Kumar A, Abraham M. Experimental analysis of vehicle operation parameters affecting emission behavior of public transport buses operating on alternative diesel fuels. In Proceedings of TRB conference, Washington, D.C. 2008.

This is an open access article licensed under the terms of the Creative Commons Attribution Non-Commercial License (http://creativecommons.org/licenses/ by-nc/3.0/) which permits unrestricted, non-commercial use, distribution and reproduction in any medium, provided the work is properly cited. 